\title{
Are mortgage lenders guilty of the housing bubble? A UK perspective
}

Article

Accepted Version

Xiao, Q. and Devaney, S. (2016) Are mortgage lenders guilty of the housing bubble? A UK perspective. Applied Economics, 48 (45). pp. 4271-4290. ISSN 1466-4283 doi:

https://doi.org/10.1080/00036846.2016.1156231 Available at https://centaur.reading.ac.uk/65512/

It is advisable to refer to the publisher's version if you intend to cite from the work. See Guidance on citing.

Published version at: http://www.tandfonline.com/doi/full/10.1080/00036846.2016.1156231

To link to this article DOI: http://dx.doi.org/10.1080/00036846.2016.1156231

Publisher: Taylor \& Francis

All outputs in CentAUR are protected by Intellectual Property Rights law, including copyright law. Copyright and IPR is retained by the creators or other copyright holders. Terms and conditions for use of this material are defined in the End User Agreement.

\section{www.reading.ac.uk/centaur}

\section{CentAUR}

Central Archive at the University of Reading

Reading's research outputs online 


\title{
Are Mortgage Lenders Guilty of the Housing Bubble? A UK perspective
}

\author{
Qin Xiao $^{1}$ and Steven Devaney ${ }^{2}$
}

This is an Accepted Manuscript of an article published by Taylor \& Francis in Applied Economics on 30/03/2016, available online: http://www.tandfonline.com/doi/full/10.1080/00036846.2016.1156231

\begin{abstract}
:
Existing theoretical models of house prices and credit rely on continuous rationality of consumers, an assumption that has been frequently questioned in recent years. Meanwhile, empirical investigations of the relationship between prices and credit are often based on national-level data, which is then tested for structural breaks and asymmetric responses, usually with subsamples. Meen (1999) argues that local markets are structurally different from one another and so the coefficients of any estimated housing market model should vary from region to region. We investigate differences in the price-credit relationship for 12 regions of the UK. Markov-switching is introduced to capture asymmetric market behaviours and turning points. Results show that credit abundance had a large impact on house prices in Greater London and nearby regions alongside a strong positive feedback effect from past house price movements. This impact is even larger in Greater London and the South East of England when house prices are falling, which are the only instances where the credit effect is more prominent than the positive feedback effect. A strong positive feedback effect from past lending activity is also present in the loan dynamics. Furthermore, bubble probabilities extracted using a discrete Kalman filter neatly capture market turning points.
\end{abstract}

Key words: regional house prices, housing credit, Markov-switching, asymmetric responses, turning points

JEL code: G12, G21, R15

\footnotetext{
${ }^{1}$ Corresponding author: Hull University Business School, University of Hull, Cottingham Road, Hull, HU6 7RX, phone: +44 (0) 1482 463172, email: q.xiao@ hull.ac.uk

${ }^{2}$ Henley Business School, University of Reading, Reading, RG6 6AH, phone: +44 (0) 118378 6657, email: s.devaney@reading.ac.uk
} 


\section{Introduction}

A generally accepted view is that irresponsible lending was the prime culprit behind the steep ascent of house prices and the ensuing 2007-8 financial crisis that affected the US and many other developed economies. Excessive and poorly allocated credit also holds a prominent place in explanations of numerous other financial and economic crises that the world has suffered over the previous century (BIS, 2001, Wong, 2001, Gerlach and Peng, 2004, Borio and Lowe, 2002, IMF, 2000, Herring and Wachter, 2002, Herring and Wachter, 1999, Drees and Pazarbaşioğlu, 1998). Alternative perspectives on explanatory factors are far less prominent, except in rare cases (see (Reinhart and Rogoff, 2008, Kahn, 2009)). Therefore, studying the impact of lending on asset prices and house prices, in particular, is an important exercise, but the exploration of other plausible explanations also matters for enriching our understanding of recurrent financial crises. This is an area in which the current study hopes to contribute.

The United Kingdom (UK) has experienced phenomenal growth in housing wealth in recent decades, from $£ 364.7$ billion at the beginning of 1983 to over $£ 4$ trillion at the end of 2007 (Oxford Economics (OE) data). This is a tenfold increase over a period when retail prices rose by only 153 per cent ${ }^{\mathrm{i}}$ and the physical dwelling stock expanded by less than 25 per cent. ${ }^{\text {ii }}$ These numbers imply that increases in house prices are the primary contributor to the rise in this country's housing wealth, a view supported by published house price indices such as the Halifax Price Index, which rose by 558 per cent over the same period, equating to $7.12 \%$ per annum. This makes the UK an interesting case study for testing the role of credit in driving price increases and the possible presence of housing bubbles. Empirical study of the UK is facilitated by the accessibility of good quality house price and mortgage lending data.

House prices in the UK have received a great deal of attention in recent decades from policymakers and economic commentators. A major reason for this attention derives from the belief that rising house prices drive consumption upwards. ${ }^{\text {iii }}$ It is now recognised that increasing house prices have a significant wealth effect on consumption and the major models of the UK economy now incorporate housing wealth alongside financial wealth in their consumption functions.

The wealth effect of housing refers to the fact that households, who attempt to smooth consumption over the life cycle, will spend and borrow more when the value of their housing asset increases. It is often claimed that house price appreciation can redistribute wealth but not increase it in aggregate, and that the wealth effect on consumption and investment is ambiguous a priori. A permanent increase in house prices will have a positive wealth effect on landlords and home-owners; it will nevertheless have a negative income effect on tenants and prospective first-time buyers (Aoki et al., 2004, Goodhart and Hofmann, 2008). This view is valid when the majority of transactions take place among the regular residents of an economy. However, in an open economy such as the UK, where foreign buyers constitute a major driver of certain housing markets (e.g. Central London) in recent years, redistribution can occur in a rising market from foreigners to the regular residents.

Besides a wealth effect, scholars also recognize the importance of a collateral effect. Higher house prices increase housing demand from borrowing-constrained households, leading to credit expansion by financial institutions. A rise in credit supply may, in turn, have repercussions on house prices because it lowers the lending rate and stimulates economic activity. As a result, prices may rise in the short-run with speculation encouraged by higher 
expected capital gains. ${ }^{\text {iv }}$ This makes the housing market prone to substantial price swings. The cyclicality of house prices can thus lead to considerable variations in households' collateral position over the market cycle. It has been observed that the amount of secured borrowing is closely related to this collateral position and that the spread of mortgage rates over the risk-free rate varies with the collateral position of each household (Aoki et al., 2004).

Financial systems in industrialized countries have undergone a process of liberalization and deregulation since the 1970s. Goodhart et al. (2004) argue that these institutional and regulatory changes are likely to have increased the pro-cyclicality of financial systems by nurturing pro-cyclical lending practices of banks, thus strengthening the links between the financial sector and property prices. Goodhart and Hofmann (2008) observe that many industrialized countries have experienced extraordinarily strong growth in money and credit accompanied by strong growth in house prices in recent decades.

The United Kingdom went through significant liberalisation of the mortgage market in the 1980s. Between 1980 and 1986, a series of regulatory measures were removed in the UK to improve competition in the mortgage market. Building societies were allowed to access wholesale funding markets; banks were allowed to compete directly with building societies in the mortgage market; other non-banks such as department stores and insurance companies were increasingly able to offer mortgage products. These changes have resulted in increased competition and financial innovation that made withdrawing housing equity easier when house prices rise. Aoki et al. (2004) show that, prior to the mid-1980s, there was little relationship between housing equity and mortgage equity withdrawal. They became more closely linked from the late 1980s as new mortgage products made refinancing easier and cheaper.

Another important development in the mortgage market is the securitisation of consumer credit. Lowe et al. (2012) argue that securitisation of mortgages created a new circuit of global capital, while national mortgage markets became the conduit through which home owners were connected to this wave of globally sourced capital. In the UK, equity stored in owner-occupied property became much more fungible because of the very liberal mortgage market. Doms and Krainer (2007) show that innovations in the mortgage market after 2000 allowed mortgage lenders to lower down-payment requirements; and that coinciding with this and other developments in the mortgage market has been a marked increase in homeownership in the US.

To date, most studies on the price-credit nexus focus on the national housing market. Studies of UK regional housing markets have largely centred on the existence or otherwise of a 'ripple effect'. The ripple effect may be described by four distinctive features: i) regional differentials in house price growth are much greater than can be explained by incomes; ii) the regional differential in price growth is highly cyclical alongside the business cycle; iii) the relative house prices of different regions converges to a set of constants in the long-run; iv) there is an epicentre that always leads the ups and downs of regional house price gaps, and which is always more volatile than the rest (Holmans, 1990, Meen, 1999).

In his quest for the ripple effect, Meen (1999) noticed that there are significant regional differences in the way that house price growth reacts to economic conditions. He points out that the housing market of a nation may be best characterised as a series of interlinked local markets rather than a single national market. He refers this feature as spatial dependence. These local markets are structurally different owing to differences in economic conditions 
and household composition. Hence, the coefficients of any estimated housing market model must vary from region to region - this is referred to as coefficient heterogeneity.

Our study makes the following contributions to the literature. As far as we are aware, this is the first scholarly article investigating the relationship between house prices and housing credit based on regional rather than national house prices. We also make some theoretical contributions in explaining the conundrum surrounding the role of credit in the determination of house prices by constructing a model based on market opportunities. Like in Aoki et al. (2004) and in Ortalo-Magne and Rady (2006), the crucial transmission mechanism in our model is credit constraint. Unlike these models, ours does not require households to be continuously rational. The research community has become increasingly aware that the assumption of rationality, a standard feature of mainstream economic models, may not hold for all households in all times (see (Xiao, 2010, TheGuardian, 2015) for a list of references). For instance, participants in housing markets are often subject to market psychology rather than making rational deliberations between non-housing consumption and housing investment. Empirically, the inclusion of a Markov-switching state variable enables us to endogenize structural changes indicated by earlier literature (Goodhart and Hofmann, 2008), as well as asymmetrical adjustment in different phases of market cycles (Cook, 2003).

\section{Review of the literature}

Goodhart and Hofmann (2008) point out that optimal portfolio adjustment is the transmission mechanism between money and house prices. This mechanism also suggests a two-way transmission. An expansion of money reduces the marginal utility of liquid assets relative to the marginal utility of other assets. Agents rebalance asset portfolios in an attempt to restore equilibrium, resulting in increases in a broad range of asset prices (Meltzer, 1995; Nelson, 2003). By the same token, an increase in house prices alters the relative marginal utility of housing assets, triggering a portfolio rebalancing which involves a higher demand for monetary assets (Greiber and Setzer, 2007). Goodhart and Hofmann (2008) further argue that there are potentially multidirectional links between money, credit, house prices and the wider economy, and that no definite conclusions can be drawn in the absence of a fully-fledged general-equilibrium theoretical model.

There are some general equilibrium models in the theoretical literature which consider a subset of the variables mentioned in the preceding passage. Based on the financial accelerator model of Bernanke et al. (1999), Aoki et al. (2004) construct a general equilibrium model of house prices, housing investment and consumption. The model, based on the utility maximization principle, describes how credit channels amplify and propagate shocks when households choose between non-housing consumption and housing investment. In a similar vein, Ortalo-Magne and Rady (2006) propose a model of the housing market with a credit constraint and a property ladder leading from starter homes to trade-up homes. In their model, the ability of young households to afford the down payment on a starter-home is a powerful driver of the housing market. They highlight a channel whereby changes in income may yield overreaction, especially in the price of trade-up homes.

The empirical literature has been fascinated by the often observed coincidence between house price growth and credit expansion. Does this coincidence reflect merely the effects of some common driving force, such as economic policy or the business cycle, or does it reflect a direct link between the two variables? If there is a direct link, does it run from house prices to housing credit or from housing credit to house prices, or in both directions? 
Hoffman (2001), using a vector error correction model (VECM), found that the long-run development of private sector credit cannot be explained in the majority of the 16 countries investigated without including an index of average residential and commercial property prices. He further finds that, in most countries, the interaction between credit and property prices is bi-directional. Gerlach and Peng (2005) also adopt a VECM framework, in their study of Hong Kong. They found that bank lending appears to adjust to property prices in the long-run, not the reverse. In the short-run, property prices also drive bank lending, but lending does not appear to influence the short-run dynamics of prices. In the context of the Irish economy, Fitzpatrick and McQuinn (2007), again using VECM, found a mutually reinforcing long-run relationship between house prices and housing credit. In the short-run, they found that the contemporaneous value of credit growth has a positive and significant effect on house price growth; but the reverse is not true. The lagged level of credit (loan-toincome ratio) also contributed to the rate of house price growth.

In an attempt to assess the lead-lag relationships between money, credit, house prices and the macro-economy, Goodhart and Hofmann (2008) performed an analysis for a panel of 17 industrialized countries using fixed-effects panel vector autoregression (panel VAR). Their sample spanned from 1973 to 2006, but they also re-estimated their model over a shorter period from 1985 to 2006 because of suspected structural changes. Their empirical analysis shows that money growth has a significant effect on house prices and credit, credit influences money and house prices, and house prices influence both credit and money. This multidirectional link is found to be stronger over 1985 to 2006 than over the full sample period. They attribute this to financial liberalization in industrialized countries, which was discussed earlier. They further found that shocks to house prices, credit and money all have significant repercussions on GDP, CPI and interest rates. Shocks to the latter group of macroeconomic variables in turn have significant effects on house prices, money and credit. Furthermore, the impact of shocks to money and credit on house prices are stronger when house prices are rising than otherwise.

Davis and Zhu (2011) construct a simple model of property demand, stock adjustment and new construction. Credit constraint is incorporated in the demand function. Their model suggests that lending is closely related to property prices and property markets can develop cycles given plausible assumptions. Their empirical work, using VECM framework, covers 17 industrialized countries spanning the period 1970-2003. Their results show that rising commercial property prices cause credit expansion in some countries and that increasing lending boosts commercial property prices in others. They further found that property prices show particularly strong links to credit in countries where banking crises were associated with property losses during 1985-1995. Both prices and credit are strongly influenced by GDP growth.

Finally, using data from 11 OECD countries from 1920 to 2011, Bordo and Landon-Lane (2013) estimate a panel VAR in order to identify shocks that can be interpreted as loose monetary policy shocks, low inflation shocks, bank credit shocks and house price shocks. They show that loose monetary policy played an important role in housing booms along with the other shocks. They also show that, during boom periods, there is a heightened impact of all three "policy" shocks with the bank credit shock playing an important role. However, when they look at individual house price boom episodes, the cause of the price boom is not so clear. "... while on average it plays an important role, the bank credit shock is not important for the US house price boom of the 1990s and 2000s. (p.37)" Loose monetary policy and low inflation played some role, but the unexplained residual is the most important shock 
explaining the US house price boom. The authors argue that the residual could be picking up other unspecified factors such as financial innovation and the shadow banking system.

\section{The Model}

\subsection{Capital market arbitrage condition as a gravity pull}

A housing market, like any other market, is subject to arbitrage. From an investor's point of view, a housing asset should generate the same rate of return as any other asset obtainable in the wider capital market, except for a difference in risk premium. This risk premium could reflect a liquidity risk, an operational risk or a risk of capital loss. Allowing for the fact that housing has a consumption value, individuals may be willing to pay a consumption premium which is over and above the price that can be justified purely from an investment point of view. The above arguments imply a variant of the usual asset market arbitrage condition that should hold in the long-run. Hence

$$
P_{t}=\frac{E_{t}\left[P_{t+1}+R_{t}+\alpha C_{t}\right]}{1+I_{t}}
$$

where $P_{t}=$ the price of one unit of housing asset at the beginning of period $\mathrm{t} ; R_{t}=$ the imputed rent incurred at the end of period $\mathrm{t} ; I_{t}=$ the time varying market required rate of return; and $C_{t}$ $=$ a composite variable capturing any other explanatory variables, such as credit constraint, risk premium and consumption premium. The coefficient $\alpha$ shows how $C_{t}$ is related to $P_{t}$. To economize on notations, we will set $\alpha=1$ in the theoretical derivation. Define

$$
i_{t} \equiv \log \left(1+I_{t}\right)
$$

hence

$$
i_{t}=\log \left(E_{t}\left[P_{t+1}+R_{t}+C_{t}\right]\right)-\ln \left(P_{t}\right)
$$

If the transversality condition, $\lim _{i \rightarrow \infty} \rho^{i} E_{t}\left[p_{t+i}\right]=0$, is satisfied, and if the imputed rent grows at a constant rate, it can be shown (see (Xiao and Huang, 2010)) that the fundamental house price satisfies:

$$
p_{t}^{f}=\frac{\kappa-\xi}{1-\rho}+(1-\rho) \sum_{j=0}^{\infty} \rho^{j} E_{t}\left[r_{t+j}+c_{t+j}\right] . \quad 0<\rho<1
$$

where

$x=\ln (X)$, and $\rho, \kappa$, and $\xi$ are functions of the underlying structural parameters and are timeinvariant under the constant growth assumption. As $c$ includes the influence of credit constraints, relaxation of a binding constraint would have a positive impact on house prices. If expectations are adaptive/path-dependent (Nerlove, 1958, Feige, 1967) ${ }^{\mathrm{v}}$, this fundamental price will be a function of the history of the variables involved in equation 4 - these might include the lagged values of imputed rent and mortgage advances. 


\subsection{The forces of speculation under uncertainty}

The path of house prices implied by the arbitrage condition would be observed at all times if housing markets were efficient in exploiting all available information. Empirical evidence shows that stock and bond markets are semi-strong efficient (Brennan and Schwartz, 1982, Pesando, 1978, Hotchkiss and Ronen, 2002, Fama, 1970, Fama et al., 1969, Fama and French, 1988, Jaffe, 1974, Hall, 2001, Shiller, 1981), but real estate markets are different. Real estate assets are lumpy and are infrequently traded in private markets with high transaction costs. They are also location specific, requiring substantial local knowledge. This suggests that information inefficiency is an inherent feature of real estate markets. Furthermore, they can be subject to extensive intervention from local and national government, which creates an additional source of uncertainty in the form of legislative risk. As a result, real estate asset prices can deviate systematically from fundamentals for a prolonged period. This deviation can generate profit opportunities, hence inviting speculation (Case and Shiller, 1989, Guntermann and Norrbin, 1991, Maier and Herath, 2009, Beracha and Skiba, 2011, Xiao, 2010, Xiao and Huang, 2010).

Consider a positive general productivity shock which leads to a boom in the real sector of the economy. Demand rises, supply adjusts to capture the profit opportunity created by the excess demand and firms hire more workers and seek more production space. Wage rates rise in the labour market where firms compete to attract workers with the right amount of skills. The returns and values of commercial real estate assets increase with the rising demand for space. With inelastic supply ${ }^{\mathrm{vi}}$, house prices also climb up as more households can afford to own housing assets with income generated from their human and capital assets. Productivity growth is thus translated into a housing market boom.

In this changed and changing environment, it is hard for buyers and sellers of housing assets to assess their intrinsic value. The imputed rent might have changed and the housing asset premium might have shifted. Such information is not easily accessible by an average market participant. House prices at any given time are thus set by the flow demand and the flow supply, which only partly bear the signature of a rational calculation based on equation (4). Under the uncertainty, individuals may resort to momentum trading, creating a positive feedback effect. Furthermore, researchers indicate that emotion influences our decisions in many important matters (Ashkanasy and Humphrey, 2001, Ashkanasy, 2003, Fisher, 2008, Huy, 2012). Therefore, at any time, house prices may contain a bubble element $b_{t}$.

$$
p_{t}=p_{t}^{f}+b_{t}
$$

\subsection{Credit constraint as a transmission mechanism}

Suppose that borrower types are uniformly distributed between 0 and 1 . Type- 1 borrowers always repay the loan, while type-0s never do. A lender knows the distribution of borrower types, but cannot easily distinguish one from another. In order to minimize the risk of default, they set one of two constraints on every borrower:

$$
\bar{M}_{t}=\mathrm{A}_{t} P_{t} H_{t}
$$

Or 


$$
\bar{M}_{t}=\mathrm{B}_{t} Y_{t}
$$

whichever is lower. The Greek letter $A$ denotes the loan-to-value ratio, with $A \in(0,1)$, and the Greek letter $B$ the income multiple, with $B>1$. Both $A$ and $B$ are set by the lender. The Roman letter $\mathrm{M}$ denotes the size of the mortgage a household can take out, $\mathrm{Y}$ its income, and $H$ the household's desired units of housing services, which is normalized to unity from now on to avoid cluttered notation.

If neither of the constraints is binding, a household can borrow as much as it wishes at the going interest rate and the loan market would clear at the required rate of return. When one of the two constraints is binding, the amount of loan available is determined by either of the above two equations. Mathematically,

$$
M_{t}^{S}= \begin{cases}f_{S}\left(I_{t}\right)=M_{t}^{D} & f_{S}{ }^{\prime}>0 \text { with unbinding constraint } \\ \bar{M}_{t}<M_{t}^{D} \quad \text { Otherwise }\end{cases}
$$

$$
\text { With } M_{t}^{D}=f_{D}\left(I_{t}\right) \quad f_{D}{ }^{\prime}<0
$$

where $f=$ function, $M_{t}^{S}=$ mortgage supply, and $M_{t}^{D}=$ mortgage demand.

Mortgage supply may also be influenced by lender confidence on top of the mechanical rules set out above. We will gauge lender confidence with reference to mortgages in arrears in the empirical section.

Equation 8 implies that if the constraint is not binding,

$$
\frac{d M_{t}^{S} / d t}{M_{t}^{S}}=\frac{d I_{t} / d t}{I_{t}}\left(\frac{d f}{d I_{t}} \frac{I_{t}}{M_{t}^{S}}\right)
$$

Notice that $\left(\frac{d f}{d I_{t}} \frac{I_{t}}{M_{t}^{S}}\right)$ is the elasticity of mortgage supply with respect to the interest rate. In this case, house prices and income will have no bearing on mortgage supply.

If the income multiple constraint is binding, then

$$
\frac{d M_{t}^{S} / d t}{M_{t}^{S}}=\frac{d B_{t} / d t}{B_{t}}+\frac{d Y_{t} / d t}{Y_{t}}
$$

In this case a boom in the labor market will be transmitted into a boom in the housing market through the relaxation of the credit constraint in equation 4.

If the collateral constraint is binding, then 


$$
\frac{d M_{t}^{S} / d t}{M_{t}^{S}}=\frac{d A_{t} / d t}{A_{t}}+\frac{d P_{t} / d t}{P_{t}}
$$

In this case, a shock to the housing market will be transmitted to the credit market. By the same token, a bubble in the housing market will also spill over into the credit market.

The theoretical derivations imply an empirical system of the following form:

$$
\begin{aligned}
& y_{t}=X_{t} \beta+\varepsilon_{t} \\
& E[\varepsilon]=0 \\
& E\left[\varepsilon \varepsilon^{\prime}\right]=V=\left(\begin{array}{ll}
\sigma_{v v} & \sigma_{v \varsigma} \\
\sigma_{\zeta v} & \sigma_{\varsigma \varsigma}
\end{array}\right)
\end{aligned}
$$

Where

$$
y_{t}=\left(\begin{array}{l}
P_{t} \\
M_{t}
\end{array}\right), X_{t}=\left(\begin{array}{c}
x^{P} \\
x^{M}
\end{array}\right), \varepsilon_{t}=\left(\begin{array}{c}
v_{t} \\
\varsigma_{t}
\end{array}\right)
$$

The row vector $\mathrm{x}^{\mathrm{P}}$ consists of explanatory variables for house prices, and the row vector $\mathrm{x}^{\mathrm{M}}$ consists of explanatory variables for housing credit.

It is possible that agents in the housing and/or mortgage market behave asymmetrically in different phases of a market cycle. The phase of a cycle can be captured by a latent state variable and the parameters of the above model are state-dependent. The exact state that the market is in is not observable, but the probability of the state can be estimated. In this case, the above system can be rewritten as

$$
\begin{aligned}
& y_{t}=X_{t} \beta^{s_{t}}+\varepsilon_{t} \\
& E[\varepsilon]=0 \\
& E\left[\varepsilon \varepsilon^{\prime}\right]=V^{s_{t}}=\left(\begin{array}{ll}
\sigma^{s_{t}} & \sigma^{s_{t}}{ }^{s} \\
\sigma^{s_{t}} & \sigma^{s_{t}} \\
&
\end{array}\right)
\end{aligned}
$$

where $s_{t}$ is a state variable following a first-order two-state Markov chain, with transition probabilities

$$
\begin{aligned}
& \operatorname{Pr}\left(s_{t+1}=j \mid s_{t}=i, s_{t-1}=i_{1}, \ldots, \Xi_{t}\right) \\
& =\operatorname{Pr}\left(s_{t+1}=j \mid s_{t}=i\right) \\
& \equiv q_{i j} \quad i, j=1,2
\end{aligned}
$$

where $\Xi_{t}$ is the information set available at time $t$ and $q_{i j}$ is the probability that state $i$ will be followed by state $j$ given $s_{t}=i, s_{t-1}=i_{1}, \ldots$, and $\Xi_{t}$. Equation 14 states that the probability distribution of $s_{t+1}$ depends on past events alone through the value of $s_{t}{ }^{\text {vii }}$. 


\section{Empirical Analyses \\ 4.1. Data and methodology}

Our full sample consists of quarterly data for UK regional housing markets over the period 1983Q1 - 2012Q1. We begin our analysis in the mid-1980s owing to data availability, but this also coincides with significant liberalization of the UK residential mortgage market. From 1983Q1 to 2007Q4, house prices increased by 558.1 per cent in the UK as a whole and by 683.5 per cent in Greater London (Halifax, all buyers, seasonally adjusted price). The market tumbled afterwards. By 2012Q1, house prices had dropped by 18.1 per cent in the UK and 12.4 per cent within Greater London (see Figure 1). In order to assess its reliability given the price movements described above, the system set out in equations 13 and 14 is estimated using the subsample of data spanning 1983Q1 - 2007Q4. The parameters obtained are used then to assess the out-of-sample performance of the model during 2008Q1 - 2012Q1.

Twelve geographical regions are covered in this study: North $(\mathrm{N})$, Yorkshire \& Humber $(\mathrm{Y} \& \mathrm{H})$, North West (NW), East Midlands (EM), West Midlands (WM), East Anglia (EA), South West (SW), South East (SE), Greater London (GL), Wales (W), Scotland (S) and Northern Ireland (NI). The locations of these regions within the UK are shown in Figure 2. For comparison, a separate model is also estimated for UK average house prices. As the study period covers two known housing market cycles, we have a sample featuring multiple peaks and troughs with which to assess the accuracy of the estimated state transition probability as a predictor of actual turning points.

\section{INSERT FIGURES $1 \& 2$ ABOUT HERE}

\section{INSERT TABLE 1 ABOUT HERE}

Table 1 displays variables included in the regression equations at the model selection stage. Halifax standardized regional house prices are used for $\mathrm{P}^{\text {viii }}$. Ideally, regional level mortgage advances should be used in the empirical model, but the authors have no access to such data. Instead, national net mortgage advances are used as a proxy for regional M. Regional rental prices are also approximated by UK imputed rentals of owner-occupiers for the same reason. In the price equation, we include in the composite variable, $\mathrm{C}$, the affordability of mortgages (mortgage rates), the influence of ownership (owner-occupied housing stock per person), and the impact of unemployment (regional claimant count rate). In the mortgage equation, we include mortgages in arrears as an additional explanatory variable. This variable may negatively impact lender confidence regarding the future state of affairs. It may also limit the capacity of lenders to issue new loans.

In the regression, house prices were divided by gross disposable income per head. The result is a house price series that is independent of any income effect. This is henceforth referred to as the price-income multiple. Meanwhile, net mortgage advances and imputed rentals were divided by gross disposable income to create a mortgage-income ratio and a rental-income ratio, respectively. Finally, owner-occupied housing stock was divided by population to give stock-per-person. This process, on top of incorporating the influences of income and population, has the added advantage that differencing the time series, which is usually required to attain stationarity, became unnecessary. Important long-run information is thus retained and the extracted state probabilities are more likely to reflect the cyclical movements of the different regional markets. All the variables presented in Table 1 have passed Augmented 
Dickey-Fuller (ADF) and Phillips and Perron (PP) unit root tests at the conventional significance levels. ${ }^{\text {ix }}$

To reduce computation costs, the system equation models are pre-selected using no-switching three-stage-least-squares (3SLS). Variables are dropped one at a time when insignificant at the 95 per cent level at this initial stage. Selected models are then re-estimated using Markovswitching FGLS SUR. The FGLS estimator is appropriate when the disturbance term is heteroscedastic. The term SUR refers to the estimation method whereby the cross-equation covariance $\sigma_{0} \zeta$ is explicitly estimated and incorporated. The smoothed probability of the unobservable state variable $s_{t}$ for a given sample of size $\mathrm{T}, \operatorname{Pr}\left(s_{t}=i \mid \zeta_{T}\right)$, is inferred using discrete Kalman filter (Hamilton, 1994). In estimating $\operatorname{Pr}\left(s_{t}=i \mid \zeta_{T}\right)$, we assume that the DGP parameters, $\beta^{s_{t}}$ are known, when in truth they need to be estimated. This can be achieved through maximizing the log likelihood function of the observed data using EM algorithm, as EM algorithm is efficient, simple and stable (Dellaert, 2002, Xiao and Tan, 2006). Simulations are used to establish the 99,95 and 90 per cent confidence intervals for the parameter estimates, as the critical values for standard t-tests do not apply in this case (Hamilton, 1994, Horowitz, 2001, Stoffer and Wall, 1991). The joint significance of the system of equations is tested using the Wald statistic.

As part of the diagnostic checks, the estimated parameters are applied to observations between 2008 Q1 and 2012 Q1. The model performed well in both in-sample fit and out-of-sample forecast. The excellent fit has been achieved in many cases as a result of including lagged dependent variables. There is, therefore, a strong positive feedback effect in both house prices and housing credit (see Table 3 and Figure 3 below).

\subsection{Parameter estimates, model evaluation, and discussion}

4.2.1. The mortgage market

As explained earlier, UK net mortgage advances are used as a proxy for regional mortgage advances. As a result, the mortgage equation has the same explanatory variables with similar parameter estimates across different regions (Table 2). However, the estimates are not identical as the covariance structures between house prices and mortgage advances are heterogeneous across different regions. On the whole, the mortgage-income ratio is negatively and significantly affected by contemporaneous year-on-year changes in the mortgage rate. ${ }^{\mathrm{x}}$ It is also significantly and negatively affected by the contemporaneous value of the percentage of mortgages in arrears for 12 months or longer. Thus, after controlling for income, rising mortgage costs and increasing mortgage arrears deter lending activity through their effects on potential buyers and lenders. Interestingly, the impact of the second factor (arrears) is much larger than the impact of the first (mortgage rates).

For instance, for the UK as a whole, a one-unit increase in the year-on-year change of mortgage rate reduces the ratio by 0.167 in state one (the state associated with the expansionary phase of the market) or by 0.352 in state two (associated with a contracting market). In contrast, this ratio would go down by 1.224 (in state one) or 1.766 (in state two) if the percentage of mortgages in arrears were to increase by one unit. The impact of average house prices on the mortgage-income ratio is significant and positive, as expected, but it is quite small in magnitude. For example, if the price-income multiple increases by one unit, the mortgage-income ratio would increase by merely 0.070 (in state one) or 0.079 (in state two). Finally, the lagged value of the mortgage-income ratio is an important factor; if the value of this ratio increased by one 
unit in the previous quarter, its current value increases by 0.698 (in state one) or 0.713 (in state two).

\section{INSERT TABLE 2 ABOUT HERE}

It is obvious from Table 2 that the magnitude of impact of each explanatory variable varies not only across regions but also across different phases of a cycle. In a contracting market, as opposed to an expanding one, the supply of mortgages is more responsive to interest rate changes in all regional markets except for EM, WM, NW, SE and GL, and the dampening effect of mortgages in arrears on mortgage lending is far larger in all regions except for EM, WM, NW and GL. Thus, with the exception of the regional markets mentioned, our results suggest that lending activity is more sensitive to loan pricing and potential losses when the underlying collateral is deteriorating in value. Meanwhile, except for NW, GL and SE, the positive-feedback-effect represented by the lagged mortgage-income ratio is smaller in a contracting market, and, apart from NW and GL, the positive impact of price on mortgage advances is slightly larger. Thus lenders may become more cautious in following the lending momentum and slightly more aware of price movements when the housing market is collapsing.

The above observations indicate that NW and GL have behaved consistently in the way mortgage supply responding to all market influences; EM and WM are consistent with each other in their mortgage supply response to interest rates and mortgages-in-arrears; SE, on the other hand, is consistent with NW and GL in the response to interest rates and price-income changes. EM and WM are right next to each other geographically, but NW is separated from GL and SE by EM and WM. Thus, geography has a role to play, but there is no simple geographical pattern with which to convey the entire story.

\subsubsection{The housing market}

The two most important effects on house prices are credit and positive-feedback effects. The results in Table 2 show that the impact of net mortgage advances on house prices (the credit effect) is typically positive, but varies significantly across different regions. The impact is very large $(0.400-0.956)$ in the south (GL, SW, SE and EA), modest $(0.290-0.368)$ in the middle part of the country (W, WM and EM), relatively small $(0.099-0.256)$ in the north (Y\&H, N, NW and S), and insignificant in Northern Ireland. The credit effect also varies across the two states. In all cases except GL and the SE, mortgage advances have a larger effect on house prices in an expansionary housing market. This finding concurs with Goodhart and Hofmann (2008), showing that the southern regions are likely to collapse quicker than the rest of the country in a tightened credit environment. For instance, the parameter estimates of mortgageincome ratio $(\mathrm{M}(\mathrm{t}))$ for GL and EM are respectively 0.465 and 0.368 in state one, and 0.956 and 0.329 in state two.

Across both states, the positive feedback effect dominates the credit effect in all regional markets, with the exception of a contracting GL. The parameter estimates of the lagged priceincome multiple (which represents a positive-feedback effect) range from 0.840 to 1.086 in state one, and from 0.728 to 1.025 in state two. With the exception of GL, SE, and SW, the feedback effect is slightly smaller in an expanding market. As the positive feedback effect reflects price bubbles, this observation indicates that the southern regions are more prone to price bubbles than the rest of the country when the market is booming. 
Three other factors appear to have some impact on the house price-income multiple in at least one of the twelve regions. First, the stock of owner-occupied housing per person has a large and positive impact across both states for GL and WM, and in one of the two states for SW. This suggests that housing ownership has a visible impact only in a very limited number of regional markets. Second, the claimant count has a marginally significant negative effect at the 99 per cent level on the house price-income multiple in one of the two states in NI, but not in other regions. Third, the only region where house prices appear to have been directly negatively affected by interest rates is EA. This impact only appears to be important in expanding markets and is nearly negligible in a contracting market.

The estimation results indicate that the UK housing market may be roughly divided into three major submarkets: one formed by SW, SE and GL (the southern submarket); one by W, WM, $\mathrm{EM}$ and EA (the middle submarket); and the final one by $\mathrm{NW}, \mathrm{Y} \& \mathrm{H}, \mathrm{N}$ and $\mathrm{S}$ (the northern submarket). This is consistent with the conclusions of previous researchers who find that the UK housing market is segmented along roughly the same lines (MacDonald and Taylor, 1993, Meen, 1999). Regions within the same submarkets exhibit similar price responses to the availability of national mortgage credit, as well as to their own past state. However, NI is a separate entity from the rest. For the price equation, it has a different set of explanatory variables and these variables are significant at the conventional levels only in one of the two states. The model is jointly significant for all regions as indicated by the Wald statistics (Table $3)$.

\section{INSERT TABLE 3 ABOUT HERE}

\subsubsection{The state of the UK regional housing markets}

The term "state" in the current context refers to the expansion or the contraction phase of a housing market cycle. Table 2 indicates that house price growth has a slight positive impact on credit expansion, that credit expansion produces further credit expansion, which has a large positive impact on house price growth, and that house price growth breeds further price growth. These rounds of price growth, except perhaps for the initial shock, can occur without any changes to fundamentals. Hence, a price bubble is more likely to form in a rising market and so the term "state" may refer to the bubble state of the market. The smoothed probabilities of the state are extracted using the discrete Kalman filter. If the estimated probability that the price is in state one, $\operatorname{Pr}\left(s_{t+1}=1 \mid s_{t}=i\right) \equiv q_{i 1}, i=1,2$, is greater than 0.5 , we conclude that the housing market is more likely to be in a bubble state than not, and vice versa. Thus, they are interpreted as the estimated probabilities that the house price contains a bubble element (EPB).

Bear in mind that $q_{i 1}$ does not need to rise when prices rises, as the latter can do so for fundamental reasons as well. However, because of a strong feedback effect, a price bubble would grow with a rising price. Hence, $q_{i 1}$ should peak when the corresponding house price peaks and trough when the price troughs. When an estimated turning point misses the actual one by one, two, three, four or more quarters, it is marked with one, two, three or four asterisks correspondingly. Among the 12 regions, the estimates correctly predicted the turning points $36.7 \%$ of the time, missed the turning points by one quarter $16.3 \%$ of the time, by two quarters $10.2 \%$ of the time, by three quarters $8.2 \%$ of the time. That is to say that the estimates capture the turning points within $+/$ - three quarters $71.4 \%$ of the time. The estimates indicate that most regions experienced two bubble periods between 1983Q2 and 2007Q4: one in the late 1980s and one in the years before the end of 2007 (Table 4 and Figure 4). 


\section{INSERT FIGURE 4 ABOUT HERE}

\section{INSERT TABLE 4 ABOUT HERE}

The first expansion of the housing market within the sample period began in the southern submarket right at the start of the period (1983Q2). This was followed two years later by EA, and three years later by the rest of the middle submarket and by the NW region. Expansion in Y\&H and N did not begin until 1987Q1 and 1988Q1, respectively. The expansion ended first in the southern submarket and EA in 1988Q4. WM followed suit in 1989Q1, the EM and W regions in 1989Q2, and N, NW and Y\&H in 1989Q4. Neither S nor NI was caught in this cycle according to our results.

The second expansion started in GL in 1995Q4. This was followed by SE in 1996Q2, EA in 1998Q2, and SW in 1999Q2. S joined this expansion in 2000Q1 and $\mathrm{N}$ in 2000Q4. EM, WM, NW and Y\&H were relative latecomers, beginning expansion in 2001Q1. W then joined in 2001Q4 and NI eventually jumped on to the bandwagon in 2003Q1. The sign of a downturn appeared as early as 2007Q1 in NW, SW and W, and in N and NI one quarter later. By 2007Q3, most of the remaining regional markets also started turning down. Only two markets, $S$ and WM, seemed unyielding to the downward pressure by the end of the estimation sample (2007Q4).

If we are to compare regional prices with the UK national average, the expansion / contraction pattern reflected in the latter would fail to pick up the rich topography of regional house price movements that our analysis has indicated. This shows the danger of relying on a single national indicator for gauging the state of the housing market in the United Kingdom and, more broadly, the need for housing market analyses to be aware of potential regional differences.

\section{Conclusion}

The current study attempts to establish important contributing factors to the rapid ascent of UK housing wealth prior to 2007 and the ensuing economic hardship. A priori, a growth in national disposable income (the income effect), a shifting of wealth from other asset markets into housing (the portfolio effect), an influx of foreign money (the open-market effect) and an expansion of domestic housing credit (the credit effect) could have all played some part in that drama. To examine all of these effects, one needs an all-inclusive general equilibrium framework, as argued by Goodhart and Hofmann (2008). In the current study, we construct a partial equilibrium model focusing on the last factor - the expansion of domestic credit.

It is generally believed that a malfunctioning credit market was the culprit for the housing bubble prior to the 2007-8 financial crisis and is primarily responsible for the crisis itself. This study attempted to identify the extent to which the housing loan market could be held responsible. We chose to examine this question in the UK rather than in the USA or other countries because of the pronounced price movements in the UK over this period and the availability of high quality data. To date, most studies on the price-credit nexus focus on the national housing market. Meen (1999), in his quest to examine a ripple effect in prices, noticed that there are significant regional differences in the way house price growth reacted to economic conditions. Thus, we study this issue by looking at regional housing markets instead.

An analytical framework incorporating a bubble transmission mechanism between housing and credit markets was first set up. The model was then estimated using historical data for the 
period 1983Q1 to 2007Q4. Geographical differences were examined using regional house prices and structural shifts were allowed for by applying a Markov-switching technique to differentiate between expanding and contracting markets. Both in-sample and out-of-sample data (2008Q1 - 2012Q1) fit very well within the model.

The theoretical model suggests that credit constraints act as a propagation mechanism, transmitting shocks occurring in the labour and/or housing market to the mortgage market. Yet our results for UK regional housing markets suggest that the loan-to-value ratio does not appear to be an important explanatory variable. The empirical outcomes show that the price-income multiple is significant, but has a rather small explanatory power for net mortgage advances, while the variable representing unemployment is not usually significant at all. Thus, credit constraints appear to have limited power in transmitting shocks in the labour and housing markets to the mortgage market. The variable which has the largest impact on lending activity is mortgages-in-arrears. The large coefficient on this variable may primarily reflect lender confidence rather than lending capacity constraint, as total mortgages in arrears reached only 3.5 per cent at its previous peak in 1992 and 1.4 per cent at its recent peak in $2009^{\mathrm{xi}}$.

We further found that, in a falling (as opposed to a rising) market and in most regions, both interest-rates and mortgages-in-arrears have a larger negative effect and the price-income multiple has a slightly larger positive impact on mortgage lending, but the momentum effect of lending drops slightly. The larger dampening effect of mortgage in arrears is particularly destabilising in a declining market given its size. This asymmetric response may reflect procyclical lending practices of banks, as predicted by Goodhart et al. (2004), and institutional constraints faced by lenders. The larger negative impact of interest rates in a down market suggests that monetary policy can be more potent in such a market, which is of interest for policymaking. However, the supply of mortgages in some regions (e.g. EM, WM, NW, GL and SE) does not always respond to economic and market influences in the same way as in other regions. Thus, a policy or regulatory measure designed to help the market may have differential effects across different regions and the aggregate outcome may not be as anticipated.

The theoretical model suggests that rent is one of the most important drivers of house prices. Empirically, imputed rent failed to show any significant impact on the price. Interest rates reflecting the discount factor also failed to have any direct impact on prices in the majority of regional markets. Nevertheless, it has an indirect impact via the credit effect. Instead, house prices are shown to be primarily driven by a positive-feedback effect and a credit effect. Furthermore, the feedback effect is far more important that the credit effect. Thus, alone, irresponsible lending in the housing credit market could not have created one of the biggest housing bubbles in the known economic history of the United Kingdom.

We contribute to the literature theoretically by explicitly modeling credit constraint as a bubble transmission mechanism that is based on market opportunities rather than utility optimization. We also contribute to the literature empirically by examining regional differences across the United Kingdom as well as variations in different phases of market cycles in these regions. We discovered that the estimates of the state probabilities have the potential to serve as a marker for dating housing market cycles, a barometer for measuring the evolution of housing bubbles, and a predictor of market turning points. Future work may seek to establish a general equilibrium model capturing all four effects discussed earlier in this section, and improve upon our results by employing regional explanatory variables. 


\section{References}

AOKI, K., PROUDMAN, J. \& VLIEGHE, G. 2004. House prices, consumption, and monetary policy: a financial accelerator approach. Journal of Financial Intermediation, 13, 414435.

ASHKANASY, N. M. 2003. Emotions in organizations: A multilevel perspective. In: DANSEREAU, F. \& YAMMARINO, F. J. (eds.) Research in multi-level issues. Oxford, UK: Elsevier/JAI Press.

ASHKANASY, N. M. \& HUMPHREY, R. H. 2001. A multi-level view of leadership and emotions: Leading with emotional labor. In: BRYMAN, A., COLLINSON, D., GRINT, K., JACKSON, B. \& UHO-BIEN, M. (eds.) Sage Handbook of Leadership. UK: Sage.

BARKER, K. 2004. Review of Housing Supply. Available: http://image.guardian.co.uk/sysfiles/Guardian/documents/2004/03/17/Barker.pdf

BERACHA, E. \& SKIBA, H. 2011. Momentum in residential real estate. Journal of Real Estate Finance and Economics, 43, 299-320.

BERNANKE, B., GERTLER, M. \& GILCHRIST, S. (eds.) 1999. The financial accelerator in a quantitative business cycle framework.: North-Holland.

BIS 2001. 71st Annual Report. Unpublished manuscript.

BORDO, M. D. \& LANDON-LANE, J. 2013. What explains house price booms?: history and empirical evidence. NBER working paper 19584. National Bureau of Economic Research.

BORIO, C. \& LOWE, P. 2002. Asset prices, financial and monetary stability: Exploring the nexus. BIS working paper no. 114.

BRENNAN, M. J. \& SCHWARTZ, E. S. 1982. An equilibrium model of bond pricing and a test of market efficiency. Journal of Financial and Quantitative Analysis, XVII, 301329.

CASE, K. E. \& SHILLER, R. J. 1989. The Efficiency of the Market for Single-Family Homes. The American Economic Review, 79, 125-137.

COOK, S. 2003. The convergence of regional house prices in the UK. Urban Studies, 40, 22852294.

DAVIS, E. P. \& ZHU, H. B. 2011. Bank lending and commercial property cycles: Some crosscountry evidence. Journal of International Money and Finance, 30, 1-21.

DELLAERT, F. 2002. The Expectation Maximization Algorithm. GVU Center; College of Computing; Georgia Tech, GIT-GVU-02-20, .

DOMS, M. \& KRAINER, J. 2007. Innovations in mortgage markets and increased spending on housing 
Federal Reserve Bank of San Francisco Working Paper No. 05.

DREES, B. \& PAZARBAŞIOĞLU, C. 1998. The Nordic banking crisis: Pitfalls in financial liberalization? IMF occasional paper no. 161.

FAMA, E. F. 1970. Efficient capital market: a review of theory and empirical work. Journal of Finance, 25, 383-417.

FAMA, E. F., FISHER, L., JENSEN, M. C. \& ROLL, R. 1969. The adjustment of stock prices to new information. International Economic Review, 10, 1-21.

FAMA, E. F. \& FRENCH, K. R. 1988. Dividend yields and expected returns on stock returns. Journal of Political Economy, 22, 3-25.

FEIGE, E. L. 1967. Expectations and Adjustments in the Monetary Sector. The American Economic Review 57, 462-473.

FISHER, C. D. 2008. What if we took within-person performance variability seriously? . Industrial and Organizational Psychology: Perspectives on Science and Practice, 2, 185-189.

FITZPATRICK, T. \& MCQUINN, K. 2007. House prices and mortgage credit: Empirical evidence for Ireland. Manchester School, 75, 82-103.

GERLACH, S. \& PEN, W. S. 2005. Bank lending and property prices in Hong Kong. Journal of Banking \& Finance, 29, 461-481.

GERLACH, S. \& PENG, W. 2004. Bank lending and property prices in Hong Kong. Hong Kong Monetary Authority working paper.

GOODHART, C. \& HOFMANN, B. 2008. House prices, money, credit, and the macroeconomy. Oxford Review of Economic Policy, 24, 180-205.

GOODHART, C., HOFMANN, B. \& SEGOVIANO, M. 2004. Bank regulation and macroeconomic fluctuations. Oxford Review of Economic Policy, 20, 591-615.

GUNTERMANN, K. \& NORRBIN, S. 1991. Empirical tests of real estate market efficiency. The Journal of Real Estate Finance and Economics, 4, 297-313.

HALL, R. 2001. Struggling to understand the stock market---the 2001 ely lecture. American Economic Review 91, 1-11.

HAMILTON, J. D. 1994. Time series analysis, Princeton University Press.

HERRING, R. J. \& WACHTER, S. 1999. Real estate booms and banking busts: An international perspective The Group of 30, occasional papers. Washington, D.C.

HERRING, R. J. \& WACHTER, S. (eds.) 2002. Asset price bubbles: Implications for monetary, regulatory and international policies: MIT Press. 
HOFFMAN, B. 2001. The determinants of private sector credit in industrialised countries: Do property prices matter? . Working Paper 108. Bank of International Settlements.

HOLMANS, A. 1990. House prices: changes through time at national and sub-national level. Government Economic Service Working Paper No. 110.

HOROWITZ, J. L. 2001. The bootstrap. In: HECKMAN, J. J. \& LEAMER, E. (eds.) Handbook of Econometric 2. Elsevier Science.

HOTCHKISS, E. S. \& RONEN, T. 2002. The Informational Efficiency of the Corporate Bond Market: An Intraday Analysis. Review of Financial Studies, 15, 1325-1354.

HUY, Q. 2012. Emotions and strategic organization: Opportunities for impactful research. Strategic Organization, 10, 240-247.

IMF 2000. World Economic Outlook.

JAFFE, J. F. 1974. Special information and insider trading. Journal of Business, 47, 410-428.

KAHN, J. A. 2009. Productivity swings and housing prices. Current Issues in Economics and Finance, 15.

LOWE, S. G., SEARLE, B. A. \& SMITH, S. J. 2012. From housing wealth to mortgage debt: the emergence of Britain's asset-shaped welfare state. Social policy and society, 11, $105-116$.

MACDONALD, R. \& TAYLOR, M. P. 1993. Regional house prices in Britain : Long-run relationships and short-run dynamics. Scottish Journal of Political Economy, 40, 43-55.

MAIER, G. \& HERATH, S. 2009. Real Estate Market Efficiency: A Survey of Literature. SREDiscussion 2009/07. Available: http://epub.wu.ac.at/402/1/document.pdf.

MARCH, J. G. 1988. Decisions and organizations, New York, NY, Blackwell.

MEEN, G. 1999. Regional house prices and the ripple effect: A new interpretation. Housing Studies, 14, 733-753.

NERLOVE, M. 1958. Adaptive Expectations and Cobweb Phenomena. The Quarterly Journal of Economics, 72, 227-240.

ORTALO-MAGNE, F. \& RADY, S. 2006. Housing market dynamics: On the contribution of income shocks and credit constraints. Review of Economic Studies, 73, 459-485.

PESANDO, J. E. 1978. On the Efficiency of the Bond Market: Some Canadian Evidence. Journal of Political Economy, 86, 1057-1076.

REINHART, C. M. \& ROGOFF, K. S. 2008. Is the 2007 U.S. sub-prime financial crisis so different? An international historical comparison. NBER Working Paper 13761. 
SHILLER, R. J. 1981. Do stock prices move too much to be justified by subsequent changes in dividends? The American Economic Review 71, 421-436.

STOFFER, D. S. \& WALL, K. D. 1991. Bootstrapping state-space models: Gaussian maximum likelihood estimation and the Kalman filter. Journal of the American Statistical Association, 86, 1024-1033.

THEGUARDIAN. 2015. Emotions, psychology or personality - what's your spending trigger? [Online]. The Guardian. [Accessed 06 Jan 2016 2016].

WONG, K.-Y. 2001. Housing market bubbles and the currency crisis: The case of Thailand. The Japanese Economic Review, 52, 382-404.

XIAO, Q. 2010. Crashes in real estate prices: Causes and predictability. Urban Studies, 47, $1725-1744$.

XIAO, Q. \& HUANG, W. 2010. Risk and predictability of Singapore's private residential market. Quantitative Finance, 10, 529-543.

XIAO, Q. \& TAN, G. 2006. Markov-switching unit root tests: a study of property price bubbles in Hong Kong and Seoul. The 35th Australian Conference of Economists. 


\section{Table 1 - Variables Examined During Regression Analysis}

All data are sourced from DataStream, except for the Halifax standardised regional house prices, these being obtained from the website for Lloyds Banking Group. All variables in the table were included in the regression equations at the model selection stage. Variables were dropped from the analysis if they were statistically insignificant at the 95 per cent level. (t) indicates a contemporary value and (t-1) a lagged value.

\begin{tabular}{|c|c|c|}
\hline $\begin{array}{l}\text { Explained } \\
\text { variables }\end{array}$ & $\begin{array}{l}\text { Halifax standardised regional house price } \\
\text { /UK gross disposable income per head }\end{array}$ & $\begin{array}{l}\text { UK mortgage net advances/UK gross } \\
\text { disposable income }\end{array}$ \\
\hline \multirow[t]{6}{*}{$\begin{array}{l}\text { Explanatory } \\
\text { Variables }\end{array}$} & $\begin{array}{c}\text { UK mortgage net advances/UK gross disposable } \\
\text { income }(\mathrm{M}(\mathrm{t}))\end{array}$ & $\begin{array}{l}\text { YOY change of UK mortgage rate (\%) } \\
\qquad(\mathrm{I}(\mathrm{t}))\end{array}$ \\
\hline & $\begin{array}{l}\text { UK Imputed rentals of owner-occupiers/UK } \\
\text { gross disposable income }(\mathrm{R}(\mathrm{t}))\end{array}$ & $\begin{array}{l}\text { UK mortgages } 12 \text { months or more in } \\
\text { arrears }(\%)(\mathrm{A}(\mathrm{t}))\end{array}$ \\
\hline & YOY change of UK mortgage rate $(\%)(\mathrm{I}(\mathrm{t}))$ & $\begin{array}{l}\text { UK median mortgage percent advance } \\
(\operatorname{LTV}(t))\end{array}$ \\
\hline & $\begin{array}{l}\text { UK owner-occupied housing stock } \\
(\text { Vol }) / \text { Population }(\mathrm{O}(\mathrm{t}))\end{array}$ & $\begin{array}{l}\text { UK house price/UK gross disposable } \\
\text { income per head (UK_P(t)) }\end{array}$ \\
\hline & $\begin{array}{l}\text { YOY change in regional claimant count rate (\%) } \\
\qquad(\mathrm{C}(\mathrm{t}))\end{array}$ & $\begin{array}{l}\text { Lagged UK mortgage net advances/UK } \\
\text { gross disposable income }(\mathrm{M}(\mathrm{t}-1))\end{array}$ \\
\hline & $\begin{array}{l}\text { Lagged regional house price/UK gross } \\
\text { disposable income per head }(\mathrm{P}(\mathrm{t}-1))\end{array}$ & \\
\hline
\end{tabular}


Table 2: Parameter Estimates (Sample 1983Q1 - 2007Q4)

Parameters, along with the covariance matrices, are estimated using iterative FGLS, with confidence intervals (C.I.) established using Bootstrap simulation with 1000 replications. If an estimate falls outside the 90,95 or 99 per cent C.I., it is marked with a $*$ or $* *$ or $* * *$ respectively. For instance, the coefficient of the lagged price/income ratio of East Anglia falls outside the 99 percent C.I., which implies that the probability that the true parameter takes the value of 0.843 is less than 1 per cent.

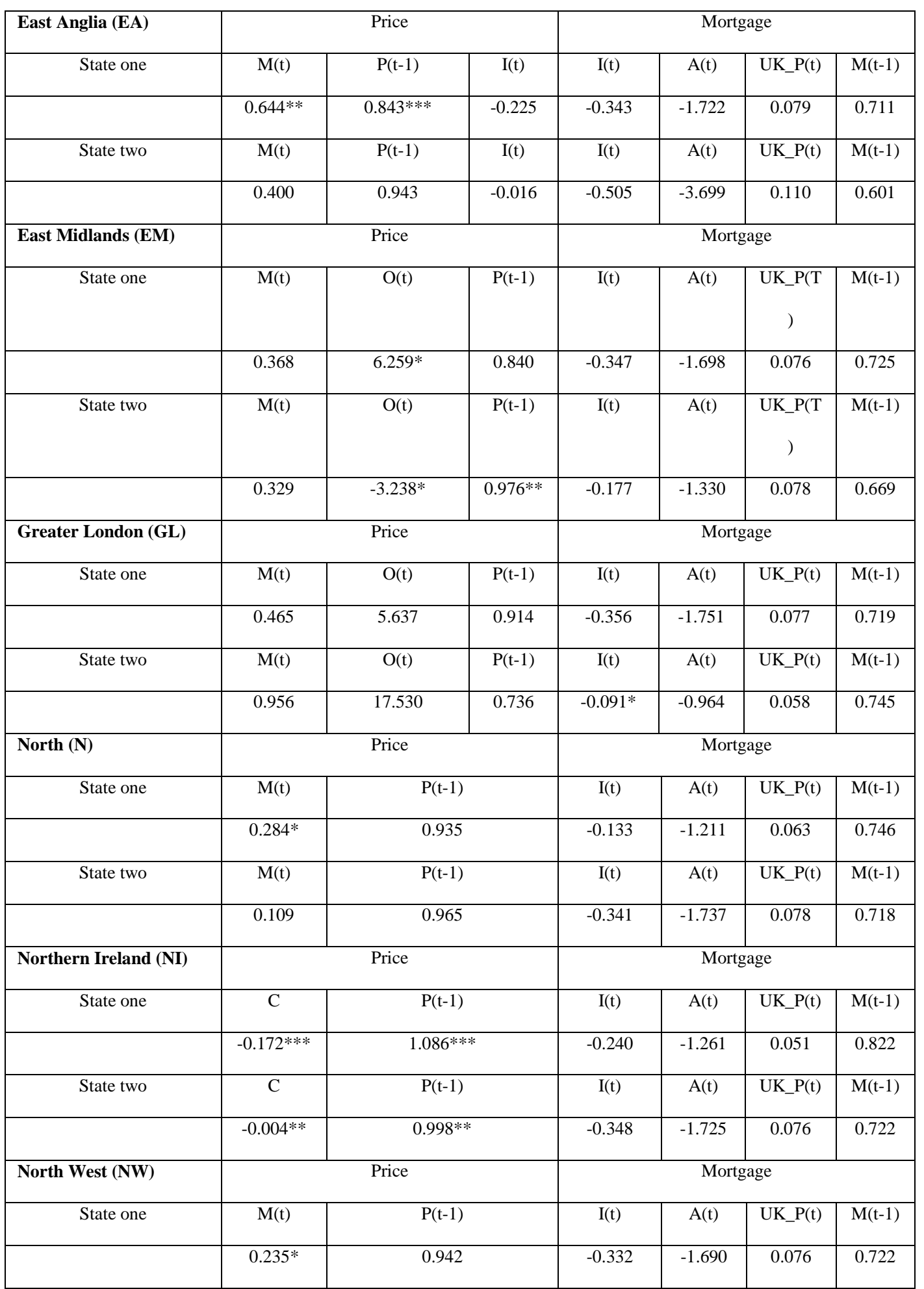




\begin{tabular}{|c|c|c|c|c|c|c|c|}
\hline State two & $\mathrm{M}(\mathrm{t})$ & \multicolumn{2}{|c|}{$\mathrm{P}(\mathrm{t}-1)$} & $\mathrm{I}(\mathrm{t})$ & $\mathrm{A}(\mathrm{t})$ & UK_P(t) & $\mathrm{M}(\mathrm{t}-1)$ \\
\hline & $0.107 * * *$ & \multicolumn{2}{|c|}{$0.967 * * *$} & -0.155 & -1.481 & 0.067 & 0.760 \\
\hline Scotland $(\mathbf{S})$ & \multicolumn{3}{|c|}{ Price } & \multicolumn{4}{|c|}{ Mortgage } \\
\hline \multirow[t]{2}{*}{ State one } & $\mathrm{M}(\mathrm{t})$ & \multicolumn{2}{|c|}{$\mathrm{P}(\mathrm{t}-1)$} & $\mathrm{I}(\mathrm{t})$ & $\mathrm{A}(\mathrm{t})$ & UK_P(t) & $\mathrm{M}(\mathrm{t}-1)$ \\
\hline & $0.257 * * *$ & \multicolumn{2}{|c|}{$0.949 * *$} & -0.310 & -1.538 & 0.063 & 0.782 \\
\hline \multirow[t]{2}{*}{ State two } & $\mathrm{M}(\mathrm{t})$ & \multicolumn{2}{|c|}{$\mathrm{P}(\mathrm{t}-1)$} & $\mathrm{I}(\mathrm{t})$ & $\mathrm{A}(\mathrm{t})$ & UK_P(t) & $\mathrm{M}(\mathrm{t}-1)$ \\
\hline & 0.099 & \multicolumn{2}{|c|}{0.972} & -0.344 & -1.726 & 0.077 & 0.717 \\
\hline South East (SE) & \multicolumn{3}{|c|}{ Price } & \multicolumn{4}{|c|}{ Mortgage } \\
\hline \multirow[t]{2}{*}{ State one } & $\mathrm{M}(\mathrm{t})$ & $\mathrm{O}(\mathrm{t})$ & $\mathrm{P}(\mathrm{t}-1)$ & $\mathrm{I}(\mathrm{t})$ & $\mathrm{A}(\mathrm{t})$ & UK_P(t) & $\mathrm{M}(\mathrm{t}-1)$ \\
\hline & 0.603 & $-16.232 * *$ & 1.002 & -0.356 & -1.713 & 0.075 & 0.726 \\
\hline \multirow[t]{2}{*}{ State two } & $\mathrm{M}(\mathrm{t})$ & $\mathrm{O}(\mathrm{t})$ & $\mathrm{P}(\mathrm{t}-1)$ & $\mathrm{I}(\mathrm{t})$ & $\mathrm{A}(\mathrm{t})$ & UK_P(t) & $\mathrm{M}(\mathrm{t}-1)$ \\
\hline & 0.839 & $18.952^{*}$ & 0.728 & -0.108 & -2.940 & 0.102 & 0.627 \\
\hline South West (SW) & \multicolumn{3}{|c|}{ Price } & \multicolumn{4}{|c|}{ Mortgage } \\
\hline \multirow[t]{2}{*}{ State one } & $\mathrm{M}(\mathrm{t})$ & $\mathrm{O}(\mathrm{t})$ & $\mathrm{P}(\mathrm{t}-1)$ & $\mathrm{I}(\mathrm{t})$ & $\mathrm{A}(\mathrm{t})$ & UK_P(t) & $\mathrm{M}(\mathrm{t}-$ \\
\hline & 0.749 & $-11.720 * * *$ & $0.930 *$ & -0.165 & -0.923 & 0.064 & 0.687 \\
\hline State two & $\mathrm{M}(\mathrm{t})$ & $\mathrm{O}(\mathrm{t})$ & $\mathrm{P}(\mathrm{t}-1)$ & $\mathrm{I}(\mathrm{t})$ & $\mathrm{A}(\mathrm{t})$ & UK_P(t) & $\mathrm{M}(\mathrm{t}-$ \\
\hline Wales $(\mathrm{W})$ & \multicolumn{3}{|c|}{ Price } & \multicolumn{4}{|c|}{ Mortgage } \\
\hline \multirow[t]{2}{*}{ State one } & $\mathrm{M}(\mathrm{t})$ & \multicolumn{2}{|c|}{$\mathrm{P}(\mathrm{t}-1)$} & $\mathrm{I}(\mathrm{t})$ & $\mathrm{A}(\mathrm{t})$ & UK_P(t) & $\mathrm{M}(\mathrm{t}-$ \\
\hline & 0.331 & & & -0.209 & -1.291 & 0.056 & 0.797 \\
\hline \multirow[t]{2}{*}{ State two } & $\mathrm{M}(\mathrm{t})$ & & & $\mathrm{I}(\mathrm{t})$ & $\mathrm{A}(\mathrm{t})$ & UK_P(t) & $\mathrm{M}(\mathrm{t}-$ \\
\hline & 0.165 & & & -0.354 & -1.748 & 0.078 & 0.717 \\
\hline West Midlands (WM) & & Price & & & Mort & & \\
\hline State one & $M(t)$ & $\mathrm{O}(\mathrm{t})$ & $\mathrm{P}(\mathrm{t}-1)$ & $\mathrm{I}(\mathrm{t})$ & $\mathrm{A}(\mathrm{t})$ & UK_P(t) & $\mathrm{M}(\mathrm{t}-$ \\
\hline & 0.317 & 5.660 & 0.872 & -0.346 & -1.678 & 0.074 & 0.730 \\
\hline State two & $\mathrm{M}(\mathrm{t})$ & $\mathrm{O}(\mathrm{t})$ & $\mathrm{P}(\mathrm{t}-1)$ & $\mathrm{I}(\mathrm{t})$ & $\mathrm{A}(\mathrm{t})$ & UK_P(t) & $\mathrm{M}(\mathrm{t}-$ \\
\hline & 0.290 & $-6.540^{*}$ & $1.025 * *$ & -0.198 & -1.480 & 0.089 & 0.618 \\
\hline $\begin{array}{l}\text { Yorkshire \& Humber } \\
(\text { Y\&H) }\end{array}$ & & Price & & & Mort & & \\
\hline State one & $\mathrm{M}($ & & $(\mathrm{t}-1)$ & $\mathrm{I}(\mathrm{t})$ & $\mathrm{A}(\mathrm{t})$ & UK_P(t) & $\begin{array}{l}\mathrm{M}(\mathrm{t}- \\
1)\end{array}$ \\
\hline
\end{tabular}




\begin{tabular}{|c|c|c|c|c|c|c|c|}
\hline & \multicolumn{2}{|c|}{0.221} & 0.955 & -0.179 & -1.239 & 0.057 & 0.785 \\
\hline \multirow[t]{2}{*}{ State two } & \multicolumn{2}{|c|}{$M(t)$} & $\mathrm{P}(\mathrm{t}-1)$ & $\mathrm{I}(\mathrm{t})$ & $\mathrm{A}(\mathrm{t})$ & UK_P(t) & $\mathrm{M}(\mathrm{t}-$ \\
\hline & \multicolumn{2}{|c|}{0.117} & 0.962 & -0.350 & -1.742 & 0.077 & 0.719 \\
\hline All UK & \multicolumn{3}{|c|}{ Price } & \multicolumn{4}{|c|}{ Mortgage } \\
\hline \multirow[t]{2}{*}{ State one } & $\mathrm{M}(\mathrm{t})$ & $\mathrm{O}(\mathrm{t})$ & UK_P(t-1) & $\mathrm{I}(\mathrm{t})$ & $\mathrm{A}(\mathrm{t})$ & UK_P(t) & $\mathrm{M}(\mathrm{t}-$ \\
\hline & 0.256 & -0.948 & $0.965 *$ & -0.167 & -1.224 & 0.070 & 0.698 \\
\hline \multirow[t]{2}{*}{ State two } & $\mathrm{M}(\mathrm{t})$ & $\mathrm{O}(\mathrm{t})$ & UK_P(t-1) & $\mathrm{I}(\mathrm{t})$ & $\mathrm{A}(\mathrm{t})$ & UK_P(t) & $\mathrm{M}(\mathrm{t}-$ \\
\hline & 0.362 & 6.089 & 0.865 & -0.352 & -1.766 & 0.079 & 0.713 \\
\hline
\end{tabular}


Table 3: Diagnostics for Regression Models

In-sample (1983Q1 - 2007Q4) and out-of-sample (2008Q1 - 2012Q1).

\begin{tabular}{|c|c|c|c|c|c|c|c|}
\hline \multirow[t]{2}{*}{ Region } & \multicolumn{3}{|c|}{ In-sample Fit } & \multicolumn{4}{|c|}{ Out-of-sample Fit } \\
\hline & $\mathrm{R}^{2}$ & Adj $R^{2}$ & $\begin{array}{l}\text { Wald } \\
\text { statistic }\end{array}$ & State $1 \mathrm{R}^{2}$ & $\begin{array}{l}\text { State } 1 \\
\text { Adj } R^{2}\end{array}$ & State $2 \mathrm{R}^{2}$ & $\begin{array}{l}\text { State } 2 \\
\text { Adj } R^{2}\end{array}$ \\
\hline EA & 0.997 & 0.996 & 195.79 & 0.959 & 0.949 & 0.984 & 0.979 \\
\hline EM & 0.996 & 0.996 & 216.28 & 0.977 & 0.971 & 0.983 & 0.978 \\
\hline GL & 0.999 & 0.998 & 205.34 & 0.992 & 0.990 & 0.960 & 0.949 \\
\hline $\mathrm{N}$ & 0.996 & 0.996 & 219.07 & 0.981 & 0.976 & 0.979 & 0.974 \\
\hline NI & 0.994 & 0.993 & 204.38 & 0.945 & 0.933 & 0.971 & 0.965 \\
\hline NW & 0.997 & 0.997 & 227.85 & 0.982 & 0.978 & 0.986 & 0.983 \\
\hline $\mathrm{S}$ & 0.997 & 0.997 & 224.68 & 0.986 & 0.982 & 0.983 & 0.979 \\
\hline SE & 0.998 & 0.998 & 202.11 & 0.982 & 0.978 & 0.966 & 0.956 \\
\hline SW & 0.997 & 0.997 & 220.26 & 0.960 & 0.949 & 0.966 & 0.957 \\
\hline W & 0.996 & 0.996 & 223.29 & 0.984 & 0.981 & 0.981 & 0.977 \\
\hline WM & 0.996 & 0.996 & 218.39 & 0.986 & 0.982 & 0.985 & 0.982 \\
\hline $\mathrm{Y} \& \mathrm{H}$ & 0.997 & 0.996 & 205.55 & 0.986 & 0.983 & 0.981 & 0.977 \\
\hline UK & 0.998 & 0.998 & 213.25 & 0.991 & 0.988 & 0.985 & 0.981 \\
\hline
\end{tabular}


Table 4 Cycles and Bubbles in UK Regional Housing Markets (c.f. Figure 6)

If the estimated probabilities that the explained variable is in state one, $\operatorname{Pr}\left(s_{t+1}=1 \mid s_{t}=i\right) \equiv q_{i 1}$, $i=1,2$, is greater than 0.5 , we conclude that the housing market is more likely to be in a bubble state than not, and vice versa. Note that $q_{i 1}$ need not to rise when the price rises as it may do so for fundamental reasons. However, if accurate, $q_{i 1}$ should peak when the corresponding house price peaks and trough when the price troughs. When an estimate misses the corresponding observed turning point by one, two, three, four or more quarters, it is marked with one, two, three, or four asterisks correspondingly. Refer to figure 4 for crossverification.

\begin{tabular}{|c|c|c|c|c|}
\hline \multirow[t]{2}{*}{ Region } & \multirow{2}{*}{$\begin{array}{c}\text { Bubble period } \\
\left(\operatorname{Prob}\left(s_{t}=1\right)>0.5\right)\end{array}$} & \multicolumn{3}{|c|}{ Observed and estimated phases of cycles } \\
\hline & & & Observed & Estimated \\
\hline EA & $\begin{array}{l}\text { 1983Q2 - 1984Q4 } \\
\text { 1989Q2 - 1992Q2 } \\
\text { 2002Q1 - 2007Q4 }\end{array}$ & $\begin{array}{l}\text { Contract } \\
\text { Expand } \\
\text { Contract } \\
\text { Expand }\end{array}$ & $\begin{array}{l}\text { 1983Q2 - 1985Q2 } \\
\text { 1985Q2 - 1988Q4 } \\
\text { 1988Q4 - 1998Q2 } \\
\text { 1998Q2 - 2007Q3 }\end{array}$ & $\begin{array}{l}\text { 1983Q2-1988Q4**** } \\
\text { 1988Q4 - 1989Q2** } \\
\text { 1989Q2 - 1998Q1* } \\
\text { 1998Q1 - 2007Q4* }\end{array}$ \\
\hline EM & $\begin{array}{l}\text { 1983Q2 - 1987Q2 } \\
\text { 1989Q3 - 1999Q3 } \\
\text { 2001Q4 - 2007Q4 }\end{array}$ & $\begin{array}{l}\text { Contract } \\
\text { Expand } \\
\text { Contract } \\
\text { Expand }\end{array}$ & $\begin{array}{l}\text { 1983Q2 - 1986Q2 } \\
\text { 1986Q2 - 1989Q2 } \\
\text { 1989Q2 - 2001Q1 } \\
\text { 2001Q1 - 2007Q3 }\end{array}$ & $\begin{array}{l}\text { 1983Q2-1988Q4**** } \\
\text { 1988Q4 - 1990Q1*** } \\
\text { 1990Q1 - 2001Q1 } \\
\text { 2001Q1 - 2007Q4* }\end{array}$ \\
\hline GL & $\begin{array}{l}\text { 1983Q2 - 1989Q1 } \\
\text { 1996Q3 - 2007Q4 }\end{array}$ & $\begin{array}{l}\text { Expand } \\
\text { Contract } \\
\text { Expand } \\
\text { Contract }\end{array}$ & $\begin{array}{l}\text { 1983Q2 - 1988Q4 } \\
\text { 1988Q4 - 1995Q4 } \\
\text { 1995Q4 - 2007Q3 } \\
\text { 2007Q3 - 2007Q4 }\end{array}$ & $\begin{array}{l}\text { 1983Q2-1988Q4 } \\
\text { 1988Q4 - 1992Q2**** } \\
\text { 1992Q2 - 2007Q3 } \\
\text { 2007Q3 - 2007Q4 }\end{array}$ \\
\hline $\mathrm{N}$ & $\begin{array}{l}\text { 1988Q4 - 1989Q4 } \\
\text { 2002Q3 - 2005Q3 }\end{array}$ & $\begin{array}{l}\text { Contract } \\
\text { Expand } \\
\text { Contract } \\
\text { Expand } \\
\text { Contract }\end{array}$ & $\begin{array}{l}\text { 1983Q2 - 1988Q1 } \\
\text { 1988Q1 - 1989Q4 } \\
\text { 1989Q4-2000Q4 } \\
\text { 2000Q4 - 2007Q2 } \\
\text { 2007Q2 - 2007Q4 }\end{array}$ & $\begin{array}{l}\text { 1983Q2-1988Q1 } \\
\text { 1988Q1-1989Q2** } \\
\text { 1989Q2-2001Q1* } \\
\text { 2001Q1-2004Q3**** } \\
\text { 2004Q3-2007Q4 }\end{array}$ \\
\hline NI & 2004Q3 - 2007Q2 & Contract & 1983Q2 - 2003Q1 & 1983Q2 - 2003Q1 \\
\hline
\end{tabular}




\begin{tabular}{|c|c|c|c|c|}
\hline \multirow[t]{3}{*}{ Region } & \multirow{2}{*}{$\begin{array}{c}\text { Bubble period } \\
\left(\operatorname{Prob}\left(s_{t}=1\right)>0.5\right)\end{array}$} & \multicolumn{3}{|c|}{ Observed and estimated phases of cycles } \\
\hline & & & Observed & Estimated \\
\hline & & $\begin{array}{l}\text { Expand } \\
\text { Contract }\end{array}$ & $\begin{array}{l}\text { 2003Q1 - 2007Q2 } \\
\text { 2007Q2 - 2007Q4 }\end{array}$ & $\begin{array}{l}\text { 2003Q1-2007Q2 } \\
\text { 2007Q2-2007Q4 }\end{array}$ \\
\hline NW & $\begin{array}{l}\text { 1983Q2 - 1984Q1 } \\
\text { 1989Q3 - 2007Q4 }\end{array}$ & $\begin{array}{l}\text { Contract } \\
\text { Expand } \\
\text { Contract } \\
\text { Expand } \\
\text { Contract }\end{array}$ & $\begin{array}{l}\text { 1983Q2 - 1986Q2 } \\
\text { 1986Q2 - 1989Q4 } \\
\text { 1989Q4 - 2001Q1 } \\
\text { 2001Q1 - 2007Q1 } \\
\text { 2007Q1 - 2007Q4 }\end{array}$ & $\begin{array}{r}\text { 1983Q2-1986Q3* } \\
\text { 1986Q3 - 1989Q2** } \\
\text { 1989Q2-1996Q3**** } \\
\text { 1996Q3-2007Q4*** } \\
\\
* * * *\end{array}$ \\
\hline $\mathrm{S}$ & 2004Q2 - 2007Q1 & $\begin{array}{l}\text { Contract } \\
\text { Expand } \\
\text { Contract }\end{array}$ & $\begin{array}{l}\text { 1983Q2 - 2001Q1 } \\
\text { 2001Q1 - 2007Q4 }\end{array}$ & $\begin{array}{l}\text { 1983Q2 - 2004Q1**** } \\
\text { 2004Q1 - 2007Q1*** } \\
\text { 2007Q1 - 2007Q4**** }\end{array}$ \\
\hline SE & $\begin{array}{l}\text { 1983Q2 - 1989Q1 } \\
\text { 2004Q4 - 2007Q4 }\end{array}$ & $\begin{array}{l}\text { Expand } \\
\text { Contract } \\
\text { Expand } \\
\text { Contract }\end{array}$ & $\begin{array}{l}\text { 1983Q2 - 1988Q4 } \\
\text { 1988Q4 - 1996Q2 } \\
\text { 1996Q2 - 2007Q3 } \\
\text { 2007Q3 - 2007Q4 }\end{array}$ & $\begin{array}{r}\text { 1983Q2-1989Q1* } \\
\text { 1989Q1-2001Q4**** } \\
\text { 2001Q4-2007Q4* } \\
* * * *\end{array}$ \\
\hline SW & $\begin{array}{l}\text { 1984Q4 - 1990Q1 } \\
\text { 2003Q4 - 2007Q1 }\end{array}$ & $\begin{array}{l}\text { Expand } \\
\text { Contract } \\
\text { Expand } \\
\text { Contract }\end{array}$ & $\begin{array}{l}\text { 1983Q2 - 1988Q4 } \\
\text { 1988Q4 - 1999Q2 } \\
\text { 1999Q2 - 2007Q1 } \\
\text { 2007Q1 -2007Q4 }\end{array}$ & $\begin{array}{l}\text { 1983Q2-1989Q1* } \\
\text { 1989Q1 - 2000Q2**** } \\
\text { 2000Q2-2007Q1 } \\
\text { 2007Q1 - 2007Q4 }\end{array}$ \\
\hline $\mathrm{W}$ & $\begin{array}{l}\text { 1988Q2 -1989Q2 } \\
\text { 2002Q4 - 2004Q3 } \\
\text { 2006Q4 - 2007Q1 }\end{array}$ & $\begin{array}{l}\text { Contract } \\
\text { Expand } \\
\text { Contract } \\
\text { Expand } \\
\text { Contract }\end{array}$ & $\begin{array}{l}\text { 1983Q2 - 1986Q2 } \\
\text { 1986Q2 - 1989Q2 } \\
\text { 1989Q2 - 2001Q4 } \\
\text { 2001Q4 - 2007Q1 } \\
\text { 2007Q1 -2007Q4 }\end{array}$ & $\begin{array}{l}\text { 1983Q2-1986Q2 } \\
\text { 1986Q2-1988Q4** } \\
\text { 1988Q4 - 2001Q4 } \\
\text { 2001Q4 - 2007Q1 } \\
\text { 2007Q1 - 2007Q4 }\end{array}$ \\
\hline
\end{tabular}




\begin{tabular}{|c|c|c|c|c|}
\hline \multirow[t]{2}{*}{ Region } & \multirow{2}{*}{$\begin{array}{c}\text { Bubble period } \\
\left(\operatorname{Prob}\left(s_{t}=1\right)>0.5\right)\end{array}$} & \multicolumn{3}{|c|}{ Observed and estimated phases of cycles } \\
\hline & & & Observed & Estimated \\
\hline WM & $\begin{array}{l}\text { 1989Q2 - 1986Q2 } \\
\text { 1989Q2 - 2007Q4 }\end{array}$ & $\begin{array}{l}\text { Contract } \\
\text { Expand } \\
\text { Contract } \\
\text { Expand }\end{array}$ & $\begin{array}{l}\text { 1983Q2 - 1986Q2 } \\
\text { 1986Q2 - 1989Q1 } \\
\text { 1989Q1 - 2001Q1 } \\
\text { 2001Q1 - 2007Q4 }\end{array}$ & $\begin{array}{l}\text { 1983Q2 - 1988Q3**** } \\
\text { 1988Q3 - 1990Q1**** } \\
\text { 1991Q4 - 2001Q1 } \\
\text { 2001Q1 - 2007Q4 }\end{array}$ \\
\hline $\mathrm{Y} \& \mathrm{H}$ & $\begin{array}{l}\text { 1988Q3 - 1989Q3 } \\
\text { 2002Q1 - 2005Q4 }\end{array}$ & $\begin{array}{l}\text { Contract } \\
\text { Expand } \\
\text { Contract } \\
\text { Expand } \\
\text { Contract }\end{array}$ & $\begin{array}{l}\text { 1983Q2 - 1987Q1 } \\
\text { 1987Q1 - 1989Q4 } \\
\text { 1989Q4 - 2001Q1 } \\
\text { 2001Q1 - 2007Q3 } \\
\text { 2007Q3 - 2007Q4 }\end{array}$ & $\begin{array}{l}\text { 1983Q2-1987Q1 } \\
\text { 1987Q1 - 1989Q2** } \\
\text { 1989Q2-2000Q2*** } \\
\text { 2000Q2 - 2004Q4**** } \\
\text { 2004Q4 - 2007Q4 }\end{array}$ \\
\hline UK & $\begin{array}{l}\text { 1986Q2 - 1989Q2 } \\
\text { 2006Q4 - 2007Q1 }\end{array}$ & $\begin{array}{l}\text { Expand } \\
\text { Contract } \\
\text { Expand } \\
\text { Contract }\end{array}$ & $\begin{array}{l}\text { 1983Q2 - 1989Q1 } \\
\text { 1989Q1 - 2001Q1 } \\
\text { 2001Q1 - 2007Q3 } \\
\text { 2007Q3 - 2007Q4 }\end{array}$ & $\begin{array}{l}\text { 1983Q2 - 1989Q1 } \\
\text { 1989Q1 - 1992Q1**** } \\
\text { 1992Q1 - 2007Q1** } \\
\text { 2007Q1 - 2007Q4 }\end{array}$ \\
\hline & & & & \\
\hline
\end{tabular}




\section{Figure 1: Trends in Key Economic Variables}

(a) House prices and the house price-income multiple: UK standardised prices

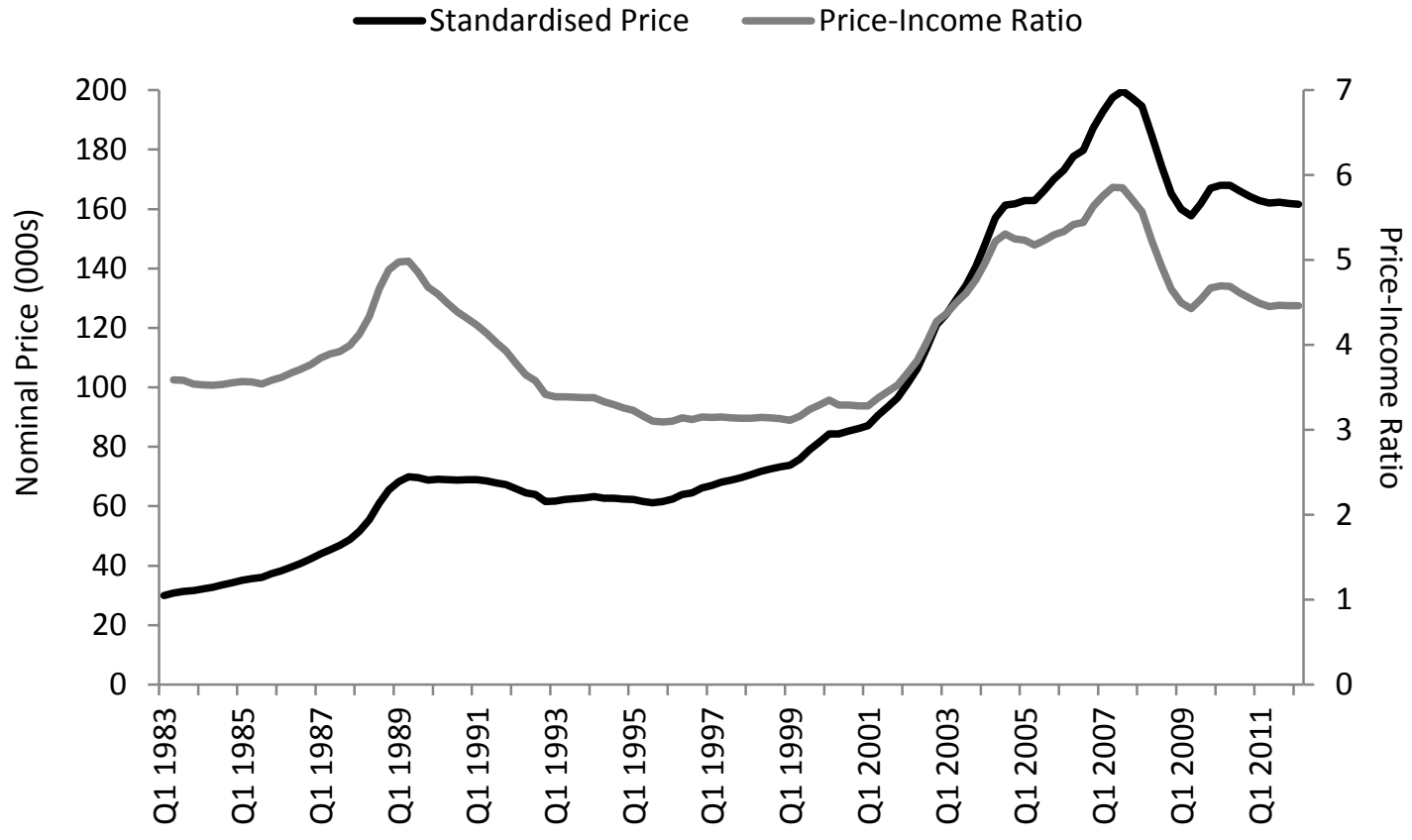

Source: Halifax House Price Index, Lloyds Banking Group

(b) Trends in lending, inflation and economic growth

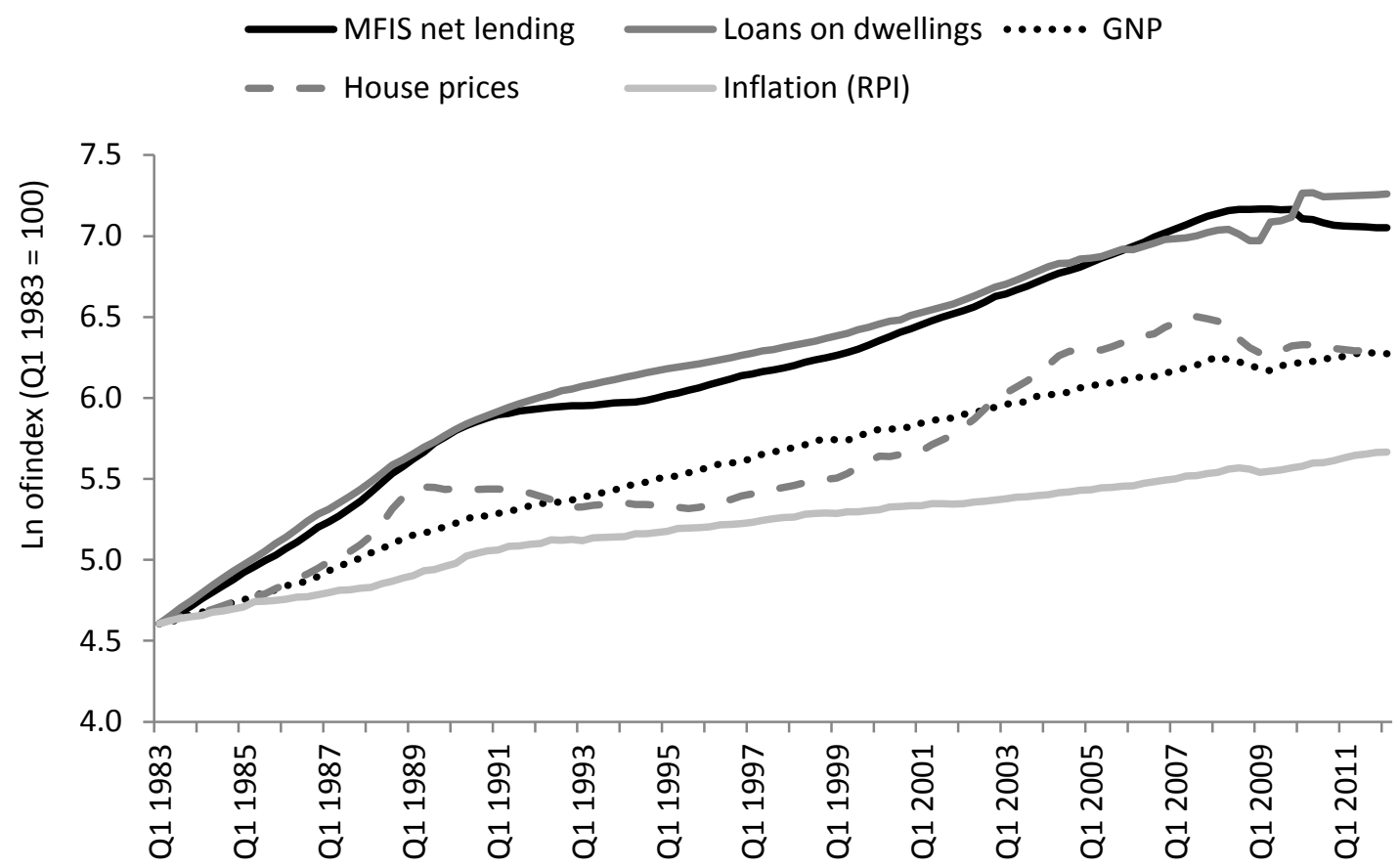

Source: Datastream 
Figure 2: UK Statistical Regions as at 31st December 2011

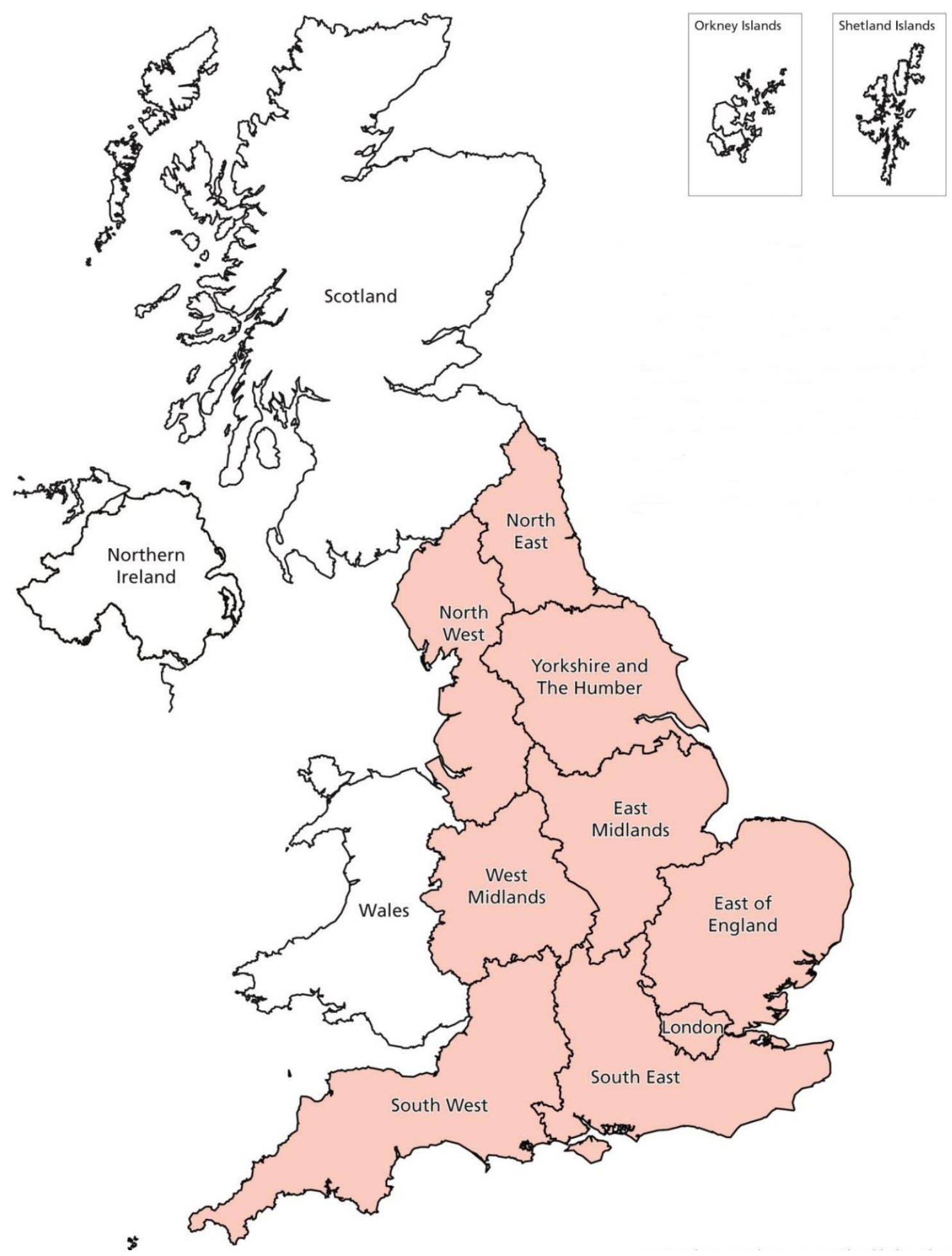

Map reproduced under the OS Open Data agreement: Contains Ordnance Survey data (C) Crown copyright and database right 2013. The shaded areas denote regions of England while Scotland, Wales and Northern Ireland are separate countries within the United Kingdom. Boundary changes mean that there are some differences between North and North West used in the paper and North East and North West as shown on the map. Similarly, there are some differences between East Anglia and South East used in the paper and East of England and South East as shown on the map. 
Figure 3: Out-of-sample Fit (2008Q1 - 2012Q1)

Price refers to price-income multiple, and mortgage to mortgage-income ratio (c.f. Table 1). Phat_i $($ Mhat_i $)=$ prediction made using state $i$ parameter estimates, $i=1,2$.

(a) East Anglia

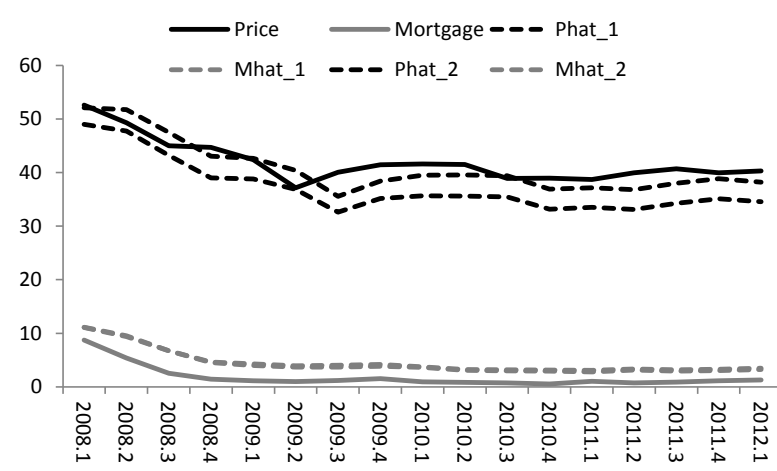

(c) Greater London

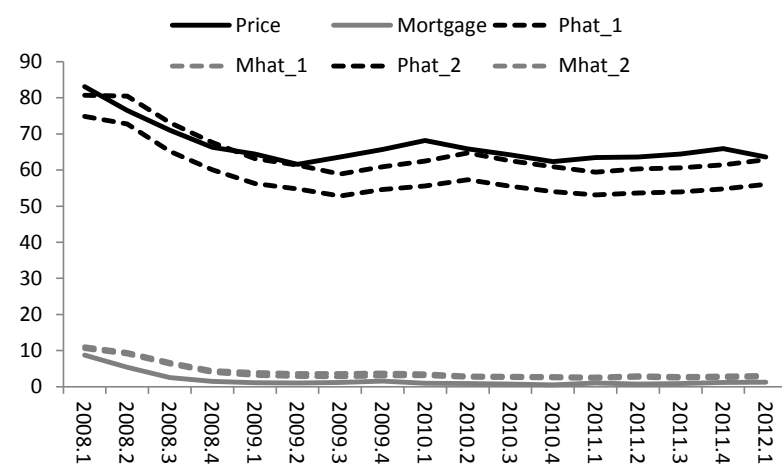

(e) Northern Ireland

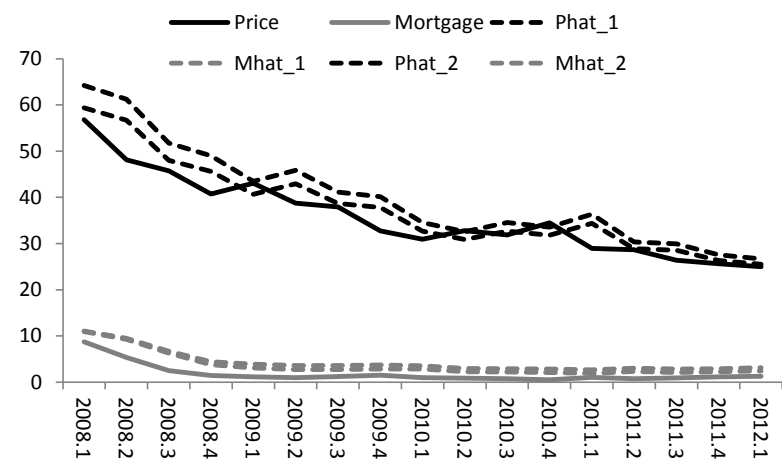

(b) East Midlands

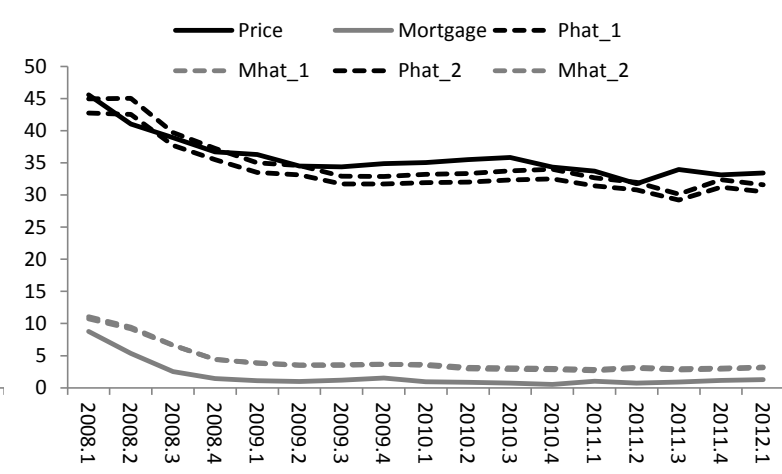

(d) North

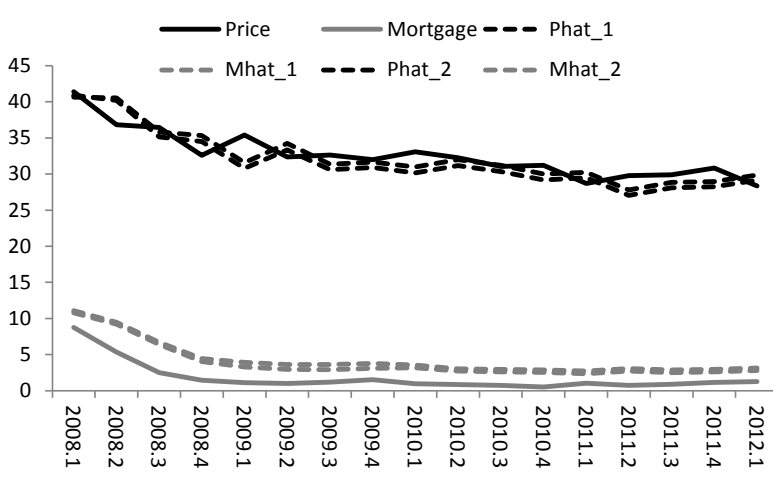

(f) North West

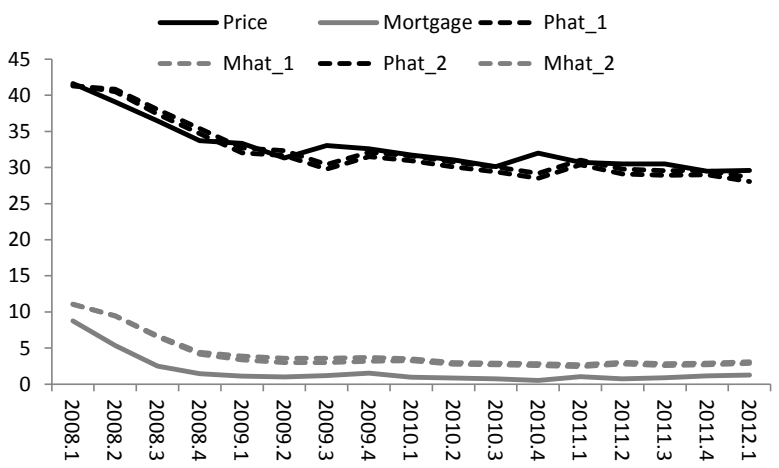


(g) Scotland

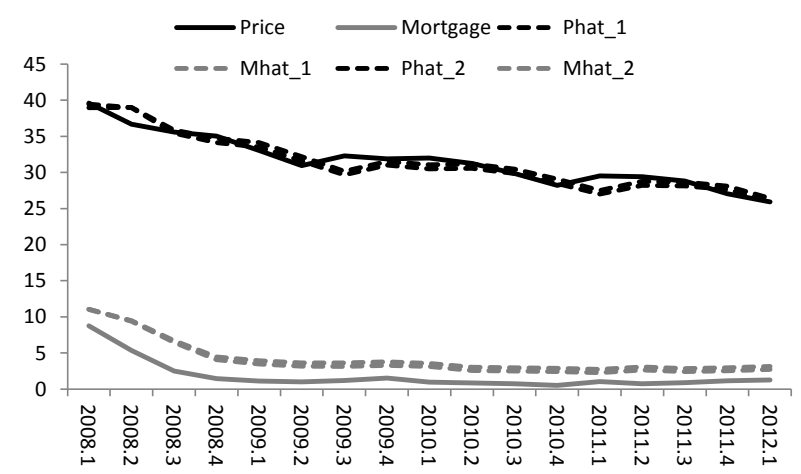

(i) South West

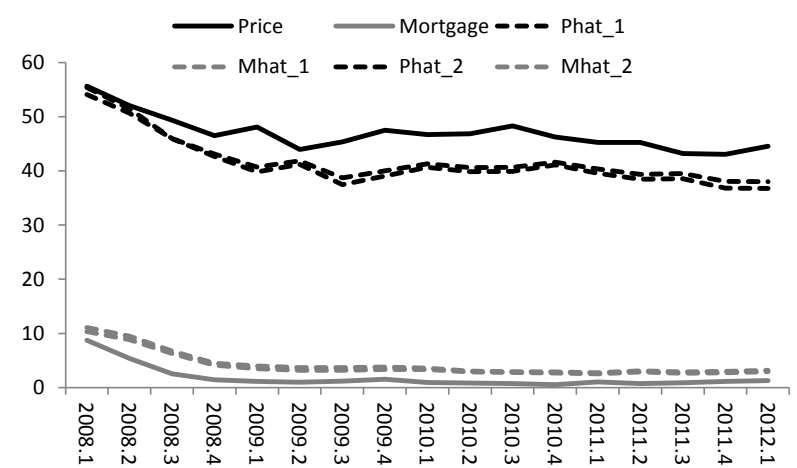

(k) West Midlands

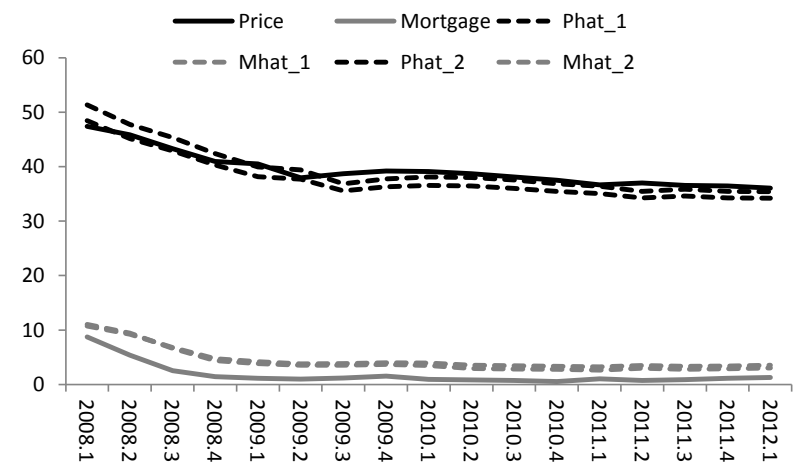

(m) All UK

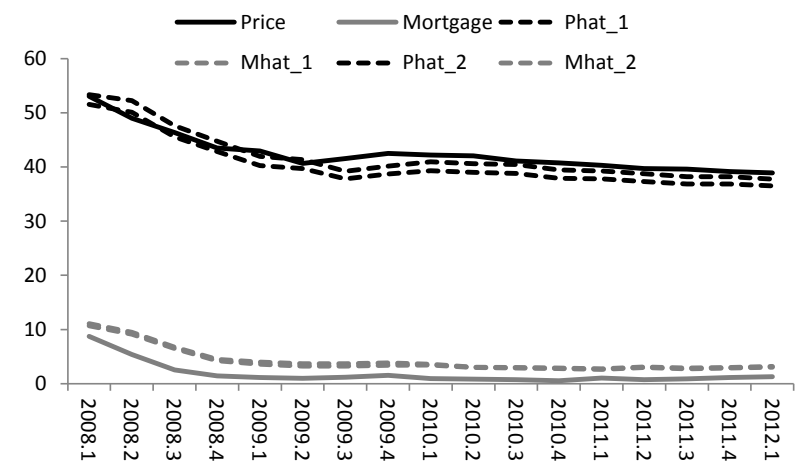

(h) South East

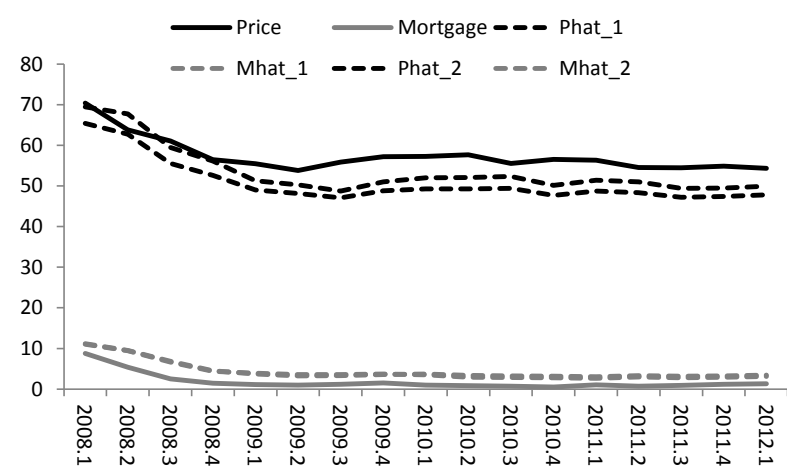

(j) Wales

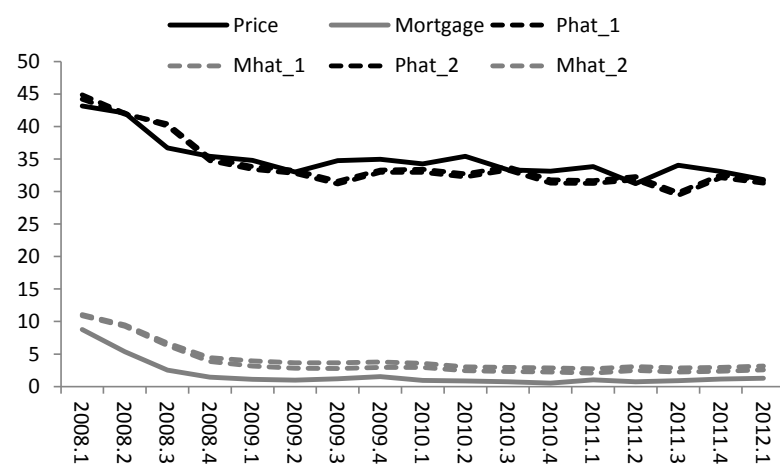

(l) Yorkshire \& Humberside

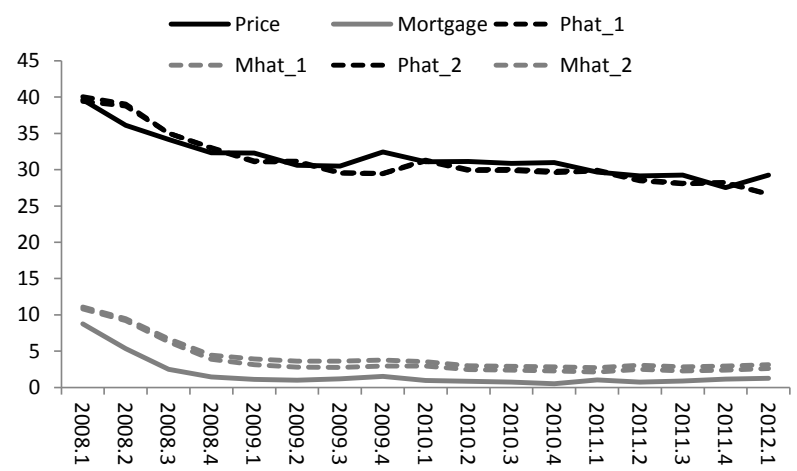




\section{Figure 4: House Price-Income Ratios and Estimated Probabilities of Bubble}

Price refers to price-income multiple and is scaled down in proportion for fitting purposes. SMp1 refers to the smoothed probability that the price contains a bubble element.

(a) East Anglia

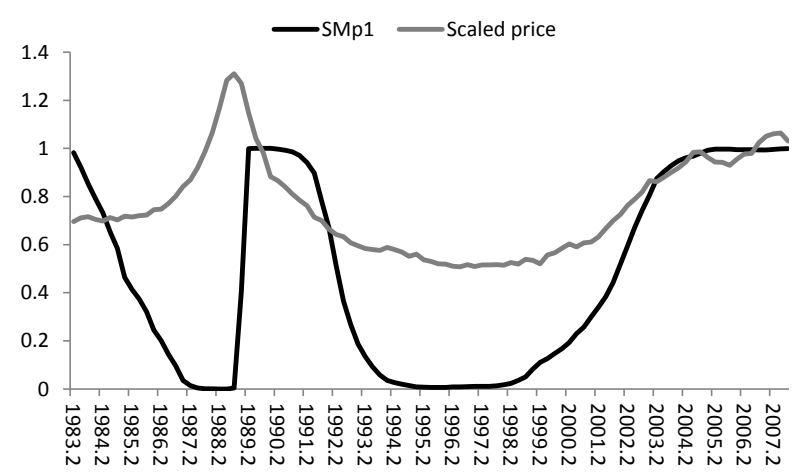

(c) Greater London

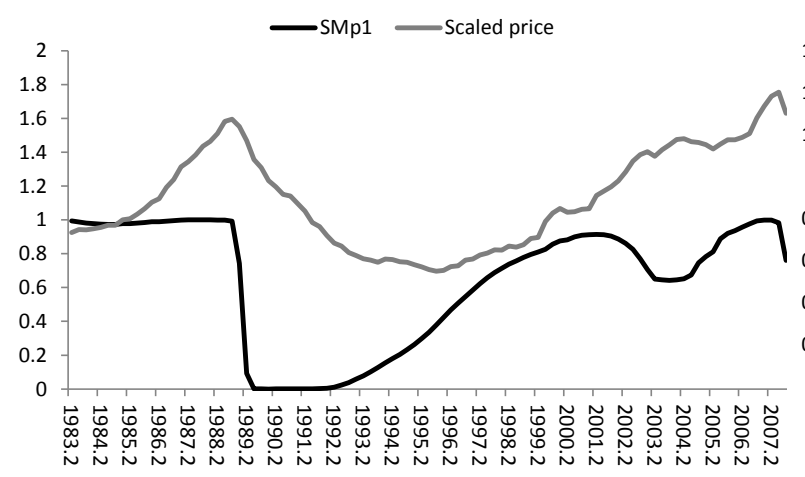

(e) Northern Ireland

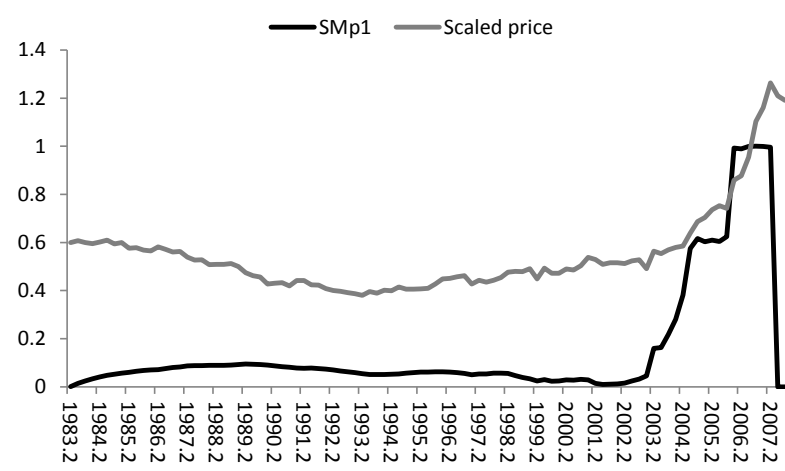

(b) East Midlands

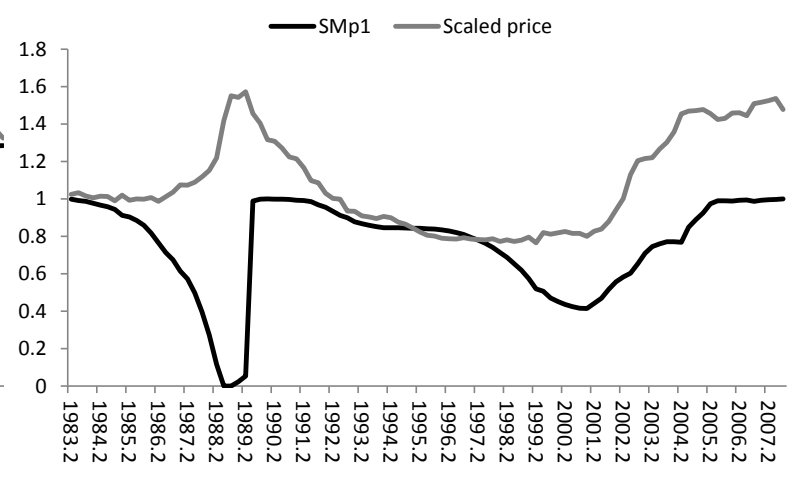

(d) North

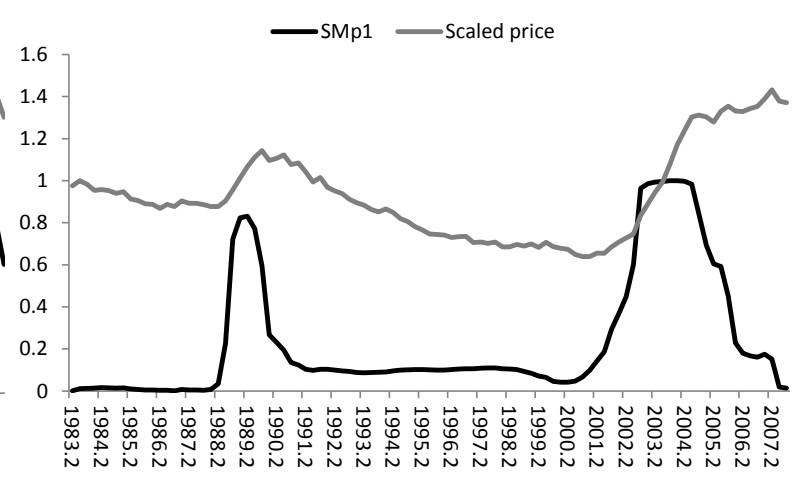

(f) North West

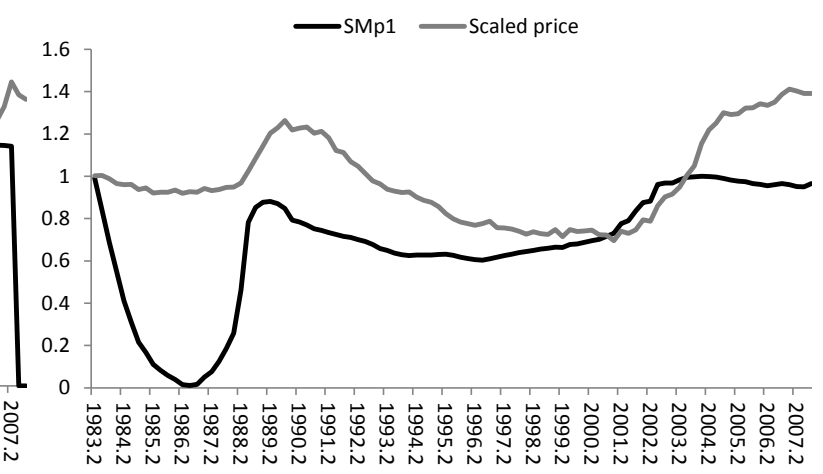


(g) Scotland

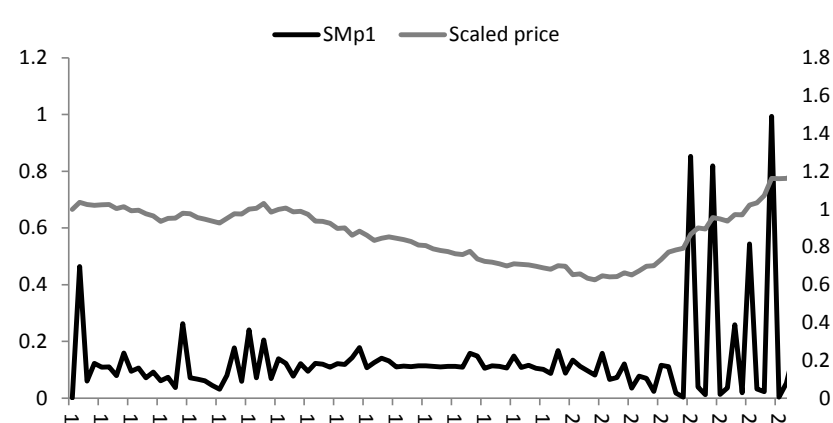

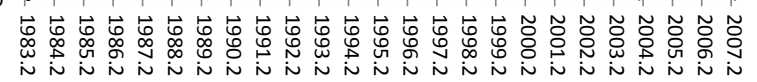

(h) South East

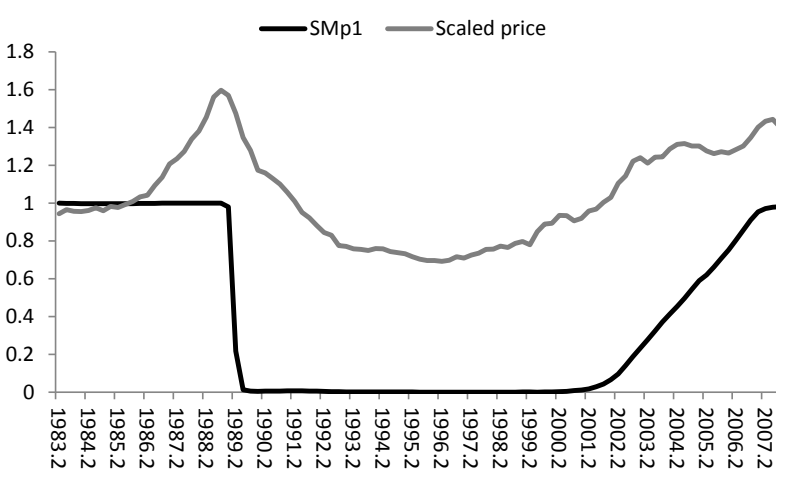

(i) South West

(j) Wales
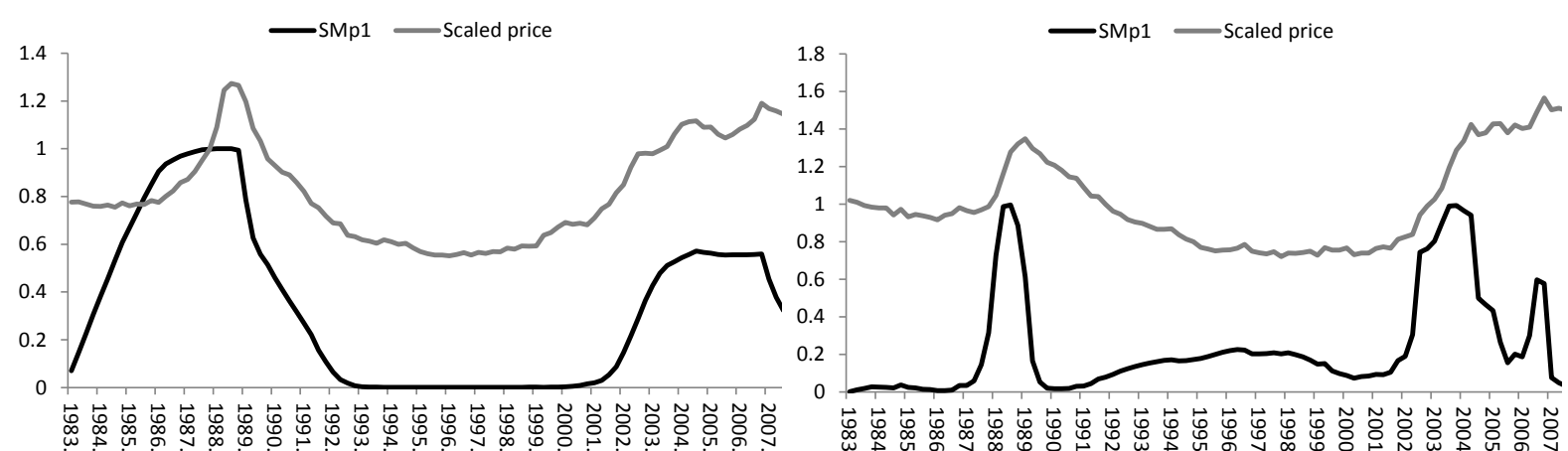

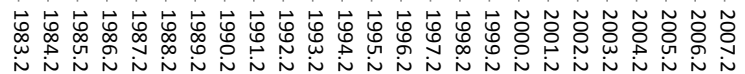

(k) West Midlands

(l) Yorkshire \& Humberside
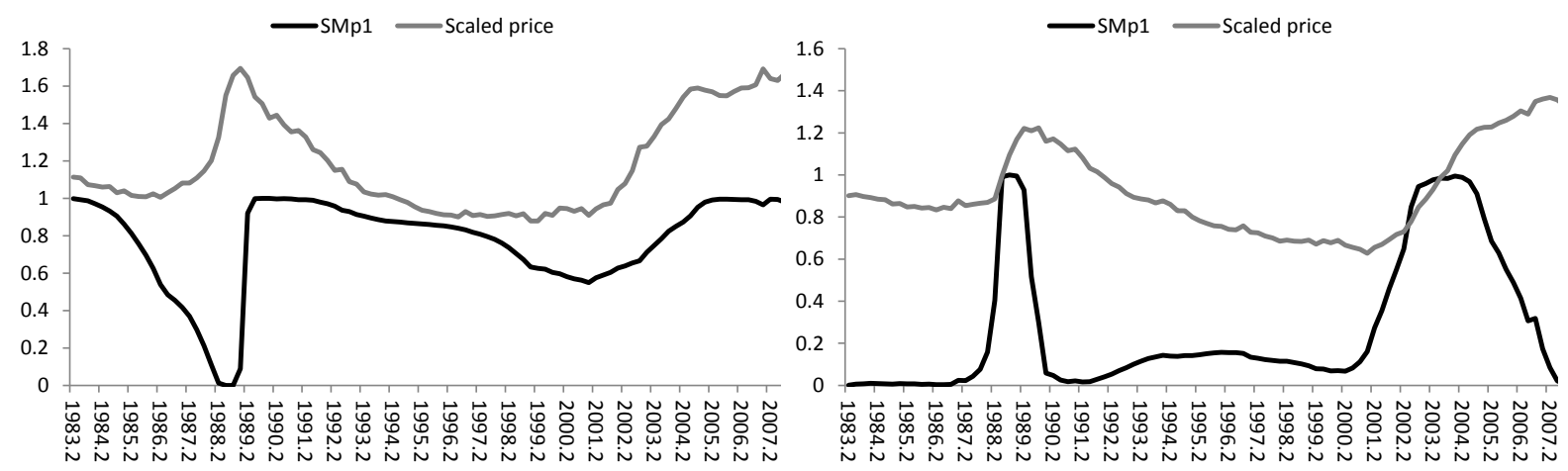

(m) All UK

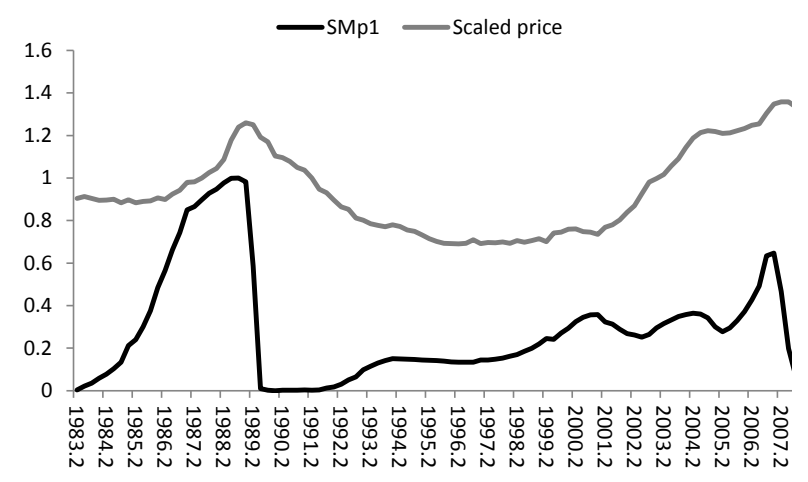


i The Retail Price Index was the primary measure of general price inflation in the UK prior to the introduction of a Consumer Price Index.

ii The dwelling stock is monitored by the UK Department for Communities and Local Government - see www.gov.uk/government/statistical-data-sets/live-tables-on-dwelling-stock-including-vacants (last accessed in January 2016).

iii For example, see the minutes of the UK Monetary Policy Committee meetings (April 2001).

iv The rise in house prices may even persist in the long-run in places where housing supply is constrained by land or regulation (Goodhart and Hofmann, 2008).

${ }^{\mathrm{v}}$ Institutionalists argue that individuals or organizations are path dependent - they apply their accustomed solutions to new problems whether or not these can be expected to work (see MARCH, J. G. 1988. Decisions and organizations, New York, NY, Blackwell.) This observation is closely related to the notion of adaptive expectations in economic theory (see references in the text).

vi The annual increase in the UK dwelling stock has been below 1 per cent between 1983 and 2007. This inelasticity in supply in the UK is largely driven by regulatory constraints (BARKER, K. 2004. Review of Housing Supply. Available: http://image.guardian.co.uk/sys-files/Guardian/documents/2004/03/17/Barker.pdf . vii Refer to Hamilton (1994) page 691 for discussion of this specification.

viii See www.lloydsbankinggroup.com/media1/economic_insight/halifax_house_price_index_page.asp (last accessed 11 October 2013)

ix The complete files containing all test statistics are not included as tables, owing to their size, but can be obtained from the authors on request.

${ }^{x}$ There is one exception, South East in the contracting phase of a cycle. As this exception is less than 5 per cent of the twenty-four parameters estimated, we regard it as a statistical outlier.

${ }^{x i}$ See https://www.gov.uk/government/statistical-data-sets/live-tables-on-repossession-activity Table 1300. 